Part of Journal of Research of the National Bureau of Standards, Volume 23, October 1939

\title{
SOIL-CORROSION STUDIES, 1937. CORROSION-RESISTANT MATERIALS AND SPECIAL TESTS
}

\author{
Kirk H. Logan
}

\section{ABSTRACT}

The soil-corrosion investigation begun in 1922 showed that many soils cause rapid corrosion of the commonly used pipe materials. The manufacturers of pipe have tried to develop materials more resistant to corrosion.

In 1932 some of these materials were buried in 15 corrosive soils for the purpose of determining their resistance to soil corrosion. Specimens are being removed at intervals of 2 or more years. The second group of specimens, including 41 metals and alloys and 11 protective coatings, was removed in 1937, and the results of their examination are contained in this paper. The results of several special tests are also given.

Several of the materials resisted very well most of the soils to which they were exposed, but none of them was unattacked by all of the soils.

The results indicate that pipe materials should be chosen with respect to the soils to which they are to be exposed.

\section{CONTENTS}

I. Nature of the investigation $\begin{array}{r}\text { Page } \\ 515\end{array}$

II. Characteristics of the test sites

III. Characteristics of soil-corrosion data _ _ _ $5 \ldots \ldots$

IV. Ferrous materials .......... 520

1. Rates of loss of weight of the specimens of pipe buried in $1932_{-}-522$

2. Maximum penetrations of the ferrous pipes buried in $1932 \ldots 523$

3. Changes in rates of maximum penetration .............. 526

4. Ferrous pipes in Merced clay adobe

5. Corrosion of chromium-iron alloy sheets_... . . _ _ _ _... 528

6. Corrosion of bolts _........

7. Comparison of maximum pit depths on specimens of different diameters . . . . .

8. Comparison of 3 -inch cast and wrought specimens with respect to their deepest pits_..... 532

9. Materials at special test sites

V. Nonferrous materials

VI. Cement-asbestos pipe

VII. Nonbituminous pipe coatings_.. 538

VIII. Summary _.

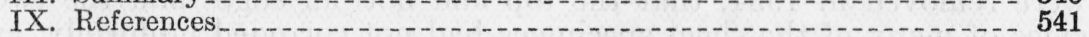

\section{NATURE OF THE INVESTIGATION}

The investigation of soil corrosion undertaken by the National Bureau of Standards in 1922 was intended primarily to determine the extent to which the corrosion observed in a study of electrolysis might be attributed to the corrosivity of the soil rather than to stray electric currents. For this purpose, specimens of the commonly used pipe materials were buried in typical soils of unknown corrosiveness 
throughout the United States. This investigation resulted in the conclusions that (1) soils differed widely in corrosivity; (2) although most soils were not severely corrosive, very corrosive soils occurred in most parts of the country; and (3) the corrosion of the commonly used pipe materials depended more upon the type of soil to which the pipe was exposed than on the composition of the pipe. These conclusions, and the requests of users of pipe, resulted in many attempts to devise ways for reducing losses caused by the action of soils on pipes. These efforts took three forms, (1) development of materials expected to be more resistant to corrosion, (2) the production of new protective coatings, and (3) treatment of the soil or the metal to overcome the corrosive action of the soil.

To assist manufacturers in the development of corrosion-resistant materials, the National Bureau of Standards arranged with 15 public utilities and other operators of pipe lines for test sites and labor by means of which typical materials could be exposed to a variety of corrosive soils. In 1932 manufacturers were invited to submit specimens of materials for exposure in these sites. Because extensive studies of bituminous protective coatings had already been made, it was decided that such coatings should not be tested, but that new types of coatings would be accepted. The announcement of the proposed tests resulted in the burial in 1932 of 29 ferrous materials, 12 nonferrous materials, and 11 protective coatings. In 1934 some of these specimens were uncovered and removed $[1,2,3] .{ }^{1}$ The present paper is a report on the specimens that were uncovered and removed in 1937. The appearance of a set of these specimens after 5 years of burial in cinders is shown in figure 1 . It should be noted that the corrosion of most of these specimens is more severe under this condition of burial in cinders than at any of the other test sites.

As an investigation reported in an earlier paper [4] showed that the maximum depth of pit observed depended in some degree upon the size of the area examined, an effort has been made in all the later investigations to have approximately the same area for all specimens. The usual 1932 specimen was a piece of $1 \frac{1}{2}$-inch pipe, 12 inches long, closed at both ends. However, it was not practical to adhere strictly to these dimensions for specimens of all materials. Some large- and some small-diameter pipes and some sheets were buried, the exposed areas being in most cases approximately the same as the external areas of the 11/2-inch pipes, 12 inches long. (See fig. 1.)

The specimens were buried crosswise in the trench, at depths of 2 to 4 feet, the sheets being set on edge, so that both sides were exposed to the same conditions. It was found, however, when specimens were removed in 1934, that the top and bottom edges and the two sides of many of the sheet specimens had not corroded uniformly, as was expected, possibly because the specimen sheets had become displaced in position when the trenches were filled.

Experience has shown that there is at least one serious objection to such tests as have just been described. Although they permit a comparison of commercial materials, in most cases it is impossible to determine from an analysis of the data why one material or one soil condition is better or worse than another. This is because the

\footnotetext{
1 Numbers in brackets indicate the literature references at the end of this paper.
} 


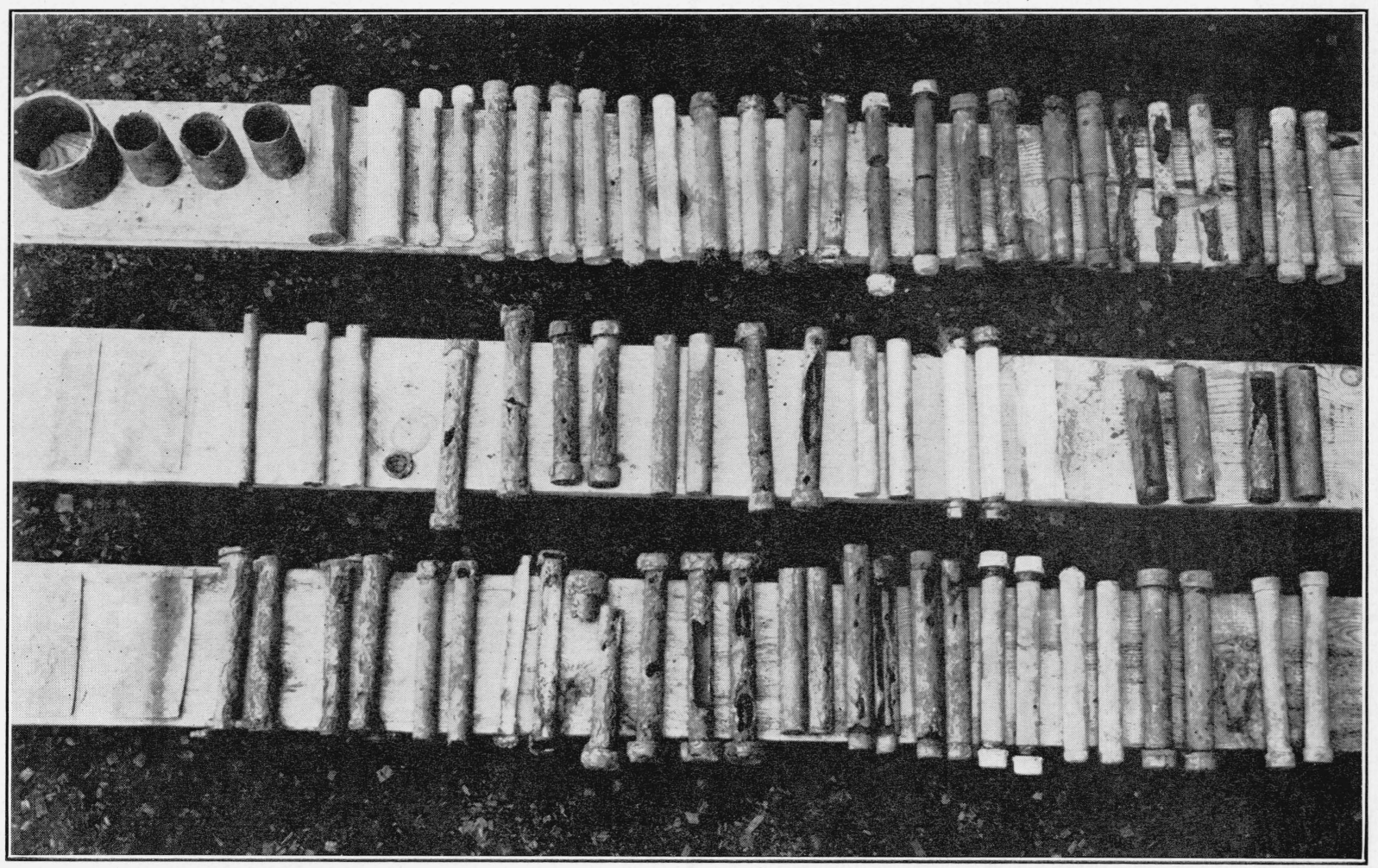

FIGURE 1.-Five-year-old specimens removed from cinders. 
materials and the soils differ in more than one respect. The data are therefore not entirely satisfactory for the development of other corrosion-resistant materials and for the determination of the causes of underground corrosion.

On the other hand, the justification for the tests as they have been conducted lies in the fact that in order to secure data suitable for the above purposes, it would be necessary to use alloys which were not commercial and to place them under soil conditions which are rarely if ever encountered by pipe lines.

Since the design of pipe materials and of pipe lines cannot be undertaken solely for the purpose of securing the minimum of corrosion, some of the scientific aspects of corrosion research have been sacrificed for the sake of obtaining data which will indicate the performance of available materials under service conditions.

\section{CHARACTERISTICS OF THE TEST SITES}

One of the most important results of the soil-corrosion investigation begun in 1922 was the evidence of the importance of soil characteristics in underground corrosion [4]. The results of the tests given in this paper can be understood only when considered in the light of the characteristics of the soils to which the materials were exposed.

It is possible that the performance of the materials was affected by the character of the backfill and by the weather conditions immediately prior and subsequent to the burial of the specimens. However, the characteristics of the soil determine to a large extent the effects of the backfill and of the weather on corrosion.

The soils with which this report deals were selected for the purpose of studying the resistance of pipe materials to underground corrosion. The governing principle in their selection, therefore, was that they should represent different kinds of corrosive conditions. Descriptions of these soils will be given in a later report.

The physical and chemical properties of the soils which might be expected to influence their corrosiveness are shown in table $1 .{ }^{2}$ The aeration of the soils was estimated from careful inspection of the test sites, employing such criteria as the texture of the soil, degree of mottling, average depth of the water table, the depth at which mottling appears, and the depth at which the specimens were placed. The terms characterizing the degree of aeration are likewise indicative of drainage conditions except for those soils which, although naturally poorly drained, receive little or no rainfall.

The aeration or drainage of the soils is indicated by the value of the "air pore space," which is the percentage of the total volume of the soil occupied by air under specified conditions. This value is determined in the laboratory from the total volume of previously saturated soil which has been compacted centrifugally by a force of 1,000 times gravity, the volume of the water retained under this force, and the volume of the soil particles. These values naturally are not indicative of the aeration of those soils in which the natural drainage is restricted by the presence of an impermeable layer below the depth at which the specimens were buried.

2 Prepared and discussed by I. A. Denison.

$175371-39-4$ 
TABLE 1.-Physical and chemical properties a of soils at test sites

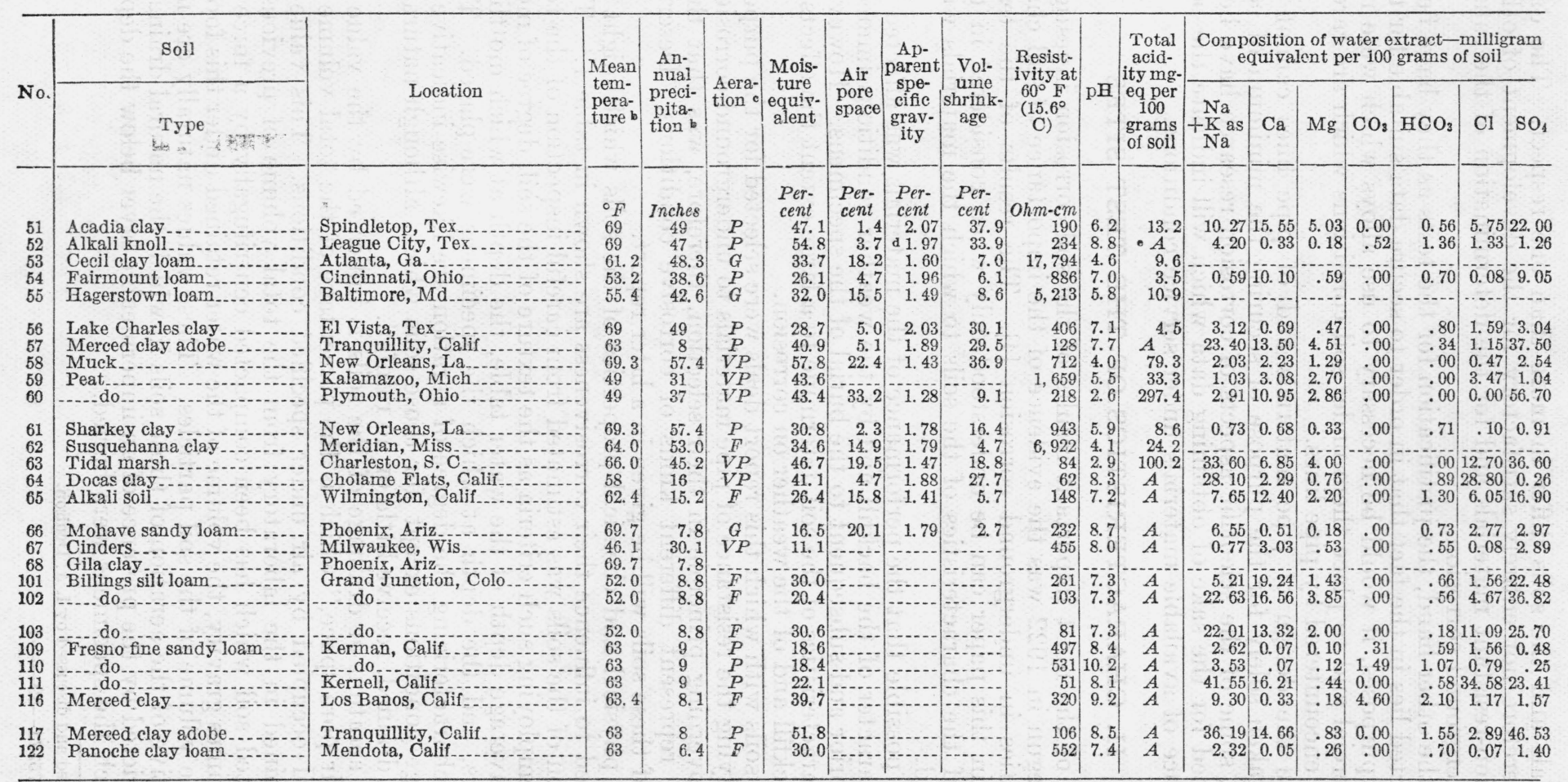

- Determinations by I. A. Denison, R. B. Hobbs, and I. C. Frost. - Data furnished by U. S. Weather Bureau. Values with no figures to the right of the decimal point are for some nearby city.
- Aeration of soils: $G=$ good, $F=$ fair, $P=$ poor, $V P=$ very poor.

d Measurement made on 20 -mesh soil after centrifuging.

- $A=$ alkaline. 
The moisture equivalent was determined by the conventional method. The previously saturated soil was subjected to a centrifugal force of 1,000 times gravity for 40 minutes and the quantity of water retained by the soil was determined.

The apparent specific gravity of the soils in their natural state was determined by measurements made on undisturbed lumps of soil from the test sites. The lumps were immersed in a dish filled with mercury, and the volume of the lump was determined by measuring the volume of the mercury displaced. The weight per unit volume was then calculated by dividing the weight of the soil by its volume.

Shrinkage was determined by measuring the change in volume on drying of a previously saturated sample of soil which had been compacted by a centrifugal force of 1,000 times gravity. The shrinkage at $105^{\circ} \mathrm{C}$ was expressed as the percentage of the volume of the moist soil.

Resistivity of the saturated soils was determined with 60-cycle alternating current.

The water extracts used for chemical analyses were prepared as follows: A suspension of soil and water in the ratio of $1: 5$ was shaken mechanically at intervals for a total of 24 hours during a period of 72 hours. The extract was decanted into a 250 -ml tall-form beaker and was filtered through a Berkfeld filter (12 by $2.5 \mathrm{~cm}$ ) into a pressure flask by suction. As the difficultly soluble salts in the soil, such as calcium carbonate, which have an important influence on the rate of corrosion, reach equilibrium very slowly, a long period of extraction was adopted. It is possible, however, that reactions occurring during this prolonged extraction have reduced the quantity of the more soluble alkali carbonates in solution in the few soils in which these salts were present.

\section{CHARACTERISTICS OF SOIL-CORROSION DATA}

Because the specimens at different test sites have not been exposed for exactly the same periods, it has seemed advisable to reduce most of the corrosion data to rates of loss of weight and rates of maximum penetration. This procedure involves the assumptions that corrosion is a continuous process and that the results of the process are proportional to the duration of the exposure.

Neither of these assumptions is strictly true, and in some cases the errors are sufficient to be of importance. Underground corrosion is largely affected by the aeration and moisture contents of the soil and these factors are in turn affected by rainfall. The irregular way in which water is supplied to the soil and the fact that two localities may differ in the distribution as well as in the amount of rainfall are illustrated in figure 2 , which shows the monthly average precipitation near four of the test sites from 1922 to 1936 . The supply of water and oxygen to the specimens did not, of course, follow the rainfall exactly, since part of the water was lost through surface runoff, but it is obvious that the irregularities in the supply of water must produce effects on corrosion which are not measured by time. The curves show that the rainfall varies from month to month and from year to year and that these variations are not the same for different parts of the country. It must follow that corrosion progresses at an irregular 
pace and that changes in the rates of corrosion at different test sites may not be synchronous.

It has been found also that at many test sites the average rate of corrosion tends to decrease as the test progresses. This decrease is much greater for some soils than for others. Rates of corrosion must therefore be used with great care in the comparison of soils or materials and in the estimation of losses or pit depths for periods greater than those for which test specimens were exposed.

As the progress of corrosion depends upon soil conditions as well as on time, it is not to be expected that when loss of weight or pit depth is plotted against the age of the specimens the result will be a smooth curve. The broken line resulting from such a procedure is the result of irregularities in weather conditions as well as of nonhomogeneous

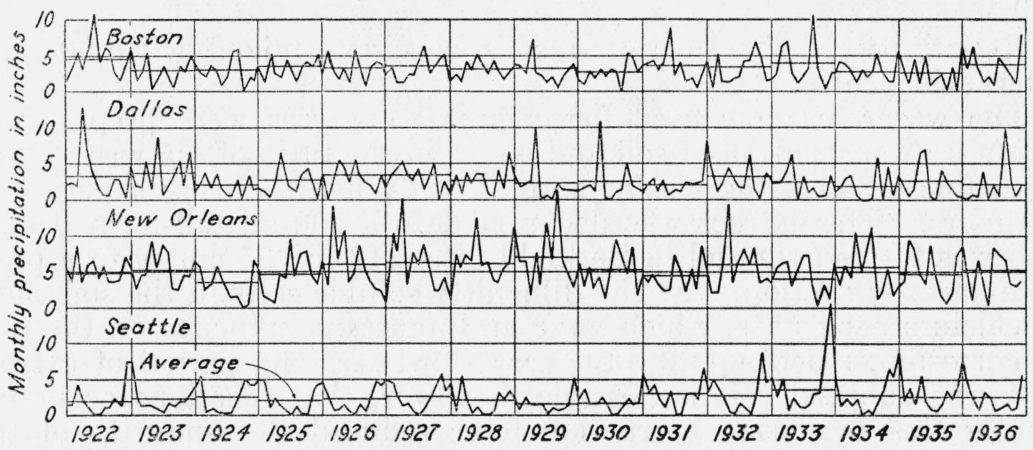

FigURE 2.-Average monthly precipitation near four test sites. (Data from record of U. S. Weather Bureau.)

soil conditions, dissimilarity of specimens, and errors in observations. The mathematical relationship of time to maximum pit depths has been discussed in another paper [5].

In studying this report, the reader should keep the following facts in mind: (1) The rates of corrosion of ferrous and perhaps of other materials also, change with the period of exposure, especially when these periods are short. (2) The depth of the deepest pit on a large area will probably be greater than that on a smaller area exposed to nominally the same condition. (3) Because temperatures, soil moisture aeration, and other conditions do not remain constant throughout a field test or throughout the life of a pipe line, the results of field tests and of observations of corrosion on pipe lines are likely to be erratic. One or two observations may depart widely from the average of a larger number. The results of a sufficient number of tests show what may be expected on the average. The results of a few tests or observations show only what may happen, but give little information as to what should be expected in any single case representing nominally the same condition. For these reasons it is advisable to expose a large number of specimens whenever a test of soil corrosion is undertaken.

\section{FERROUS MATERIALS}

The composition and dimensions of the ferrous materials removed in 1937 are given in table 2. 
TABLE 2.-Composition a and dimensions of ferrous materials

\begin{tabular}{|c|c|c|c|c|c|c|c|c|c|c|c|c|c|c|c|}
\hline \multirow{2}{*}{$\begin{array}{l}\text { Identi- } \\
\text { fication } \\
\text { letter }\end{array}$} & \multirow[b]{2}{*}{ Material } & \multirow{2}{*}{$\begin{array}{l}\text { Nomi- } \\
\text { nal di- } \\
\text { ameter } \\
\text { or } \\
\text { width }\end{array}$} & \multirow{2}{*}{ Length } & \multirow{2}{*}{$\begin{array}{l}\text { Wall } \\
\text { thick- } \\
\text { ness }\end{array}$} & \multicolumn{4}{|c|}{ Carbon } & \multirow[b]{2}{*}{$\mathrm{Si}$} & \multirow{2}{*}{ Mn } & \multirow[b]{2}{*}{$\mathrm{s}$} & \multirow[b]{2}{*}{$\mathrm{P}$} & \multirow[b]{2}{*}{$\mathrm{Cr}$} & \multirow{2}{*}{$\mathrm{Ni}$} & \multirow{2}{*}{$\mathrm{Cu}$} \\
\hline & & & & & Free & $\begin{array}{l}\text { Com- } \\
\text { bined }\end{array}$ & Total & $\begin{array}{l}\text { For } \\
\text { steel }\end{array}$ & & & & & & & \\
\hline$A$ & Puddled wrought-iron pipe & $\begin{array}{r}\text { Inches } \\
1.5\end{array}$ & $\begin{array}{r}\text { Inches } \\
12\end{array}$ & $\begin{array}{r}\text { Inches } \\
0.145\end{array}$ & $\%$ & $\%$ & $\%$ & \multirow{2}{*}{$\begin{array}{c}\% \\
0.026 \\
.02\end{array}$} & \multirow{4}{*}{$\begin{array}{l}\% \\
0.100 \\
.125 \\
2.5 \\
0.19 \\
2.13\end{array}$} & \multirow{4}{*}{$\begin{array}{c}\% \\
0.029 \\
.041 \\
.7 \\
.21 \\
1.0\end{array}$} & \multirow{4}{*}{$\begin{array}{l}\% \\
0.018 \\
.018 \\
.05\end{array}$} & \multirow{4}{*}{$\begin{array}{c}\% \\
0.160 \\
.106 \\
.4\end{array}$} & $\%$ & $\%$ & $\%$ \\
\hline$\stackrel{B}{C}$ & Low-alloy cast-iron pipe. & $\begin{array}{l}1.5 \\
1.5\end{array}$ & $\begin{array}{l}12 \\
12\end{array}$ & $\begin{array}{l}.145 \\
.25\end{array}$ & 3. 0 & 0.5 & 3.5 & & & & & & 0.3 & 0.15 & \\
\hline$D$ & $\mathrm{Ni}$-Cu steel pipe & 1.5 & 12 & .145 & & & & \multirow{2}{*}{$\begin{array}{c}.14 \\
\end{array}$} & & & & & 0.0 & 2. 47 & \multirow{2}{*}{$\begin{array}{l}1.08 \\
6.58\end{array}$} \\
\hline$E$ & High alloy cast-iron pipe... & 1.5 & & .145 & & & 2.98 & & & & & & 2.61 & 15.0 & \\
\hline$F$ & Sand-coated cast-iron pipe-... & 1.5 & 12 & .250 & 2.9 & .6 & 3.5 & \multirow{4}{*}{ - } & 1.85 & 0.5 & .75 & .7 & 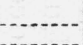 & 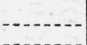 & \multirow{4}{*}{$\begin{array}{r}0.52 \\
.51 \\
.62\end{array}$} \\
\hline$\stackrel{G}{H}$ & en-hearth iron pipe $d$. & $\begin{array}{l}1.0 \\
1.5\end{array}$ & 12 & .145 & & & 0.04 & & 0.05 & .32 & .027 & .016 & & & \\
\hline$I$ & Special cast-iron pipe............ & 1.5 & 12 & .350 & $\ldots$ & $\ldots$ & 2. 53 & & 1.43 & .28 & .077 & .128 & -....- & - & \\
\hline $\boldsymbol{J}$ & do & 1.5 & 12 & .350 & & & 2.9 & & 2.04 & .83 & .060 & .248 & -....... & -..... & \\
\hline$K$ & Or-Ni steel sheet (18-8) & 3 & 11 & .025 & & & & \multirow{2}{*}{.08} & 0.33 & .44 & .022 & .015 & 17.2 & 8.95 & \multirow{2}{*}{.07} \\
\hline$\stackrel{L}{M}$ & $\begin{array}{l}\text { 6-in. } \\
\text { 3-in. }\end{array}$ & $\begin{array}{l}6 \\
3\end{array}$ & $\begin{array}{l}5 \\
5\end{array}$ & .48 & 2. 92 & .83 & 3.75 & & 1.49 & .47 & .08 & .62 & & & \\
\hline$N$ & Low-carbon steel tube & 2 & 10 & .154 & $\ldots$ & ....- & (n) & \multirow{2}{*}{.15} & (n...... & .49 & .030 & .013 & & $\ldots$. & \multirow{2}{*}{ - } \\
\hline$P$ & Cr steel tube $(5 \% \mathrm{Cr})$ & 2 & 10 & .154 & & . & - & & (n) & .46 & .025 & .012 & 5.05 & (n) & \\
\hline$R$ & Cr-Ni steel tube (18-8) & 1.5 & 12 & .145 & -....... & & . & \multirow{4}{*}{$\begin{array}{l}.05 \\
.07 \\
.06 \\
.065 \\
.070\end{array}$} & 0.28 & .46 & .011 & .015 & 17. 52 & 8.85 & \multirow{4}{*}{$\begin{array}{l}.74 \\
.95 \\
.025 \\
.021\end{array}$} \\
\hline$\underset{T}{S}$ & $\begin{array}{l}\text { Cr-Mn steel sheet (18-9) } \\
\text { Cr-Mn-Ni steel sheet }\end{array}$ & $\begin{array}{l}6 \\
6\end{array}$ & $\begin{array}{l}10 \\
10\end{array}$ & $\begin{array}{l}.063 \\
.063\end{array}$ & & & Lana & & $\begin{array}{r}.48 \\
.40\end{array}$ & $\begin{array}{l}9.44 \\
6.09\end{array}$ & 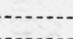 & - & $\begin{array}{l}17.78 \\
17.76\end{array}$ & $3.83^{--}$ & \\
\hline 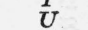 & $\mathrm{Cr}$ steel sheet $(12 \% \mathrm{Cr})$ & 4 & 6 & .063 & . & & (n) & & .28 & 0.38 & .017 & .011 & 11. 95 & 0.482 & \\
\hline$\vec{V}$ & Cr steel sheet $(17 \% \mathrm{Cr})$ & 4 & 6 & .063 & & & (n) & & .34 & .36 & .015 & .014 & 17. 08 & .092 & \\
\hline$W$ & $\mathrm{Cr}-\mathrm{Ni}$ steel sheet $(18-8$ & 4 & 6 & .063 & $\ldots$ & & ...... & .093 & .42 & .36 & .017 & .008 & 18. 69 & 9. 18 & .016 \\
\hline $\boldsymbol{X}$ & Cr steel tube $(18 \% \mathrm{Cr})$ & 1.5 & 12 & .145 & $\ldots$ & $\cdots$ & $-\cdots$ & .12 & .277 & .42 & .017 & .016 & & & \\
\hline $\boldsymbol{Y}$ & $\mathrm{Cr}$-Ni steel sheet $(22-12)$ & 4 & 6 & .063 & & & & .144 & .59 & 1.80 & .011 & .015 & 22.68 & 12. 94 & .021 \\
\hline
\end{tabular}

- These data were furnished by the manufacturers of the materials. In some cases, they may represent the average analyses of materials rather than of the specimens sub-

b Oxide and slag, $2.560 \%$. mitted for test.

- Oxide and slag, $2.681 \%$.

d Molybdenum, $0.15 \%$. 


\section{RATES OF LOSS OF WEIGHT OF THE SPECIMENS OF PIPE BURIED IN 1932}

In tables 3 and 4 are given the rates of loss of weight of specimens of wrought-iron and steel pipe, and of cast-iron pipe, respectively, that were buried for 5 years. These rates are, in most cases, based on the examination of two specimens. Usually the two specimens of the same material in the same soil yielded results which agreed closely. Occasionally, however, they differed widely. In such cases the averages of the losses have little significance. For this reason those cases in which the loss of weight of the individual specimens differed from the average by 50 percent or more and was greater than 10 grams are indicated in the table by the superscript $b$. When the losses were small, relatively large differences between two specimens are unimportant, the significant fact being that the specimens corroded very little.

TABLE 3.-Rates * of loss of weight of wrought-iron and steel pipe buried in 1982

[Ounces per square foot per year b]

\begin{tabular}{|c|c|c|c|c|c|c|c|c|c|c|}
\hline \multicolumn{2}{|r|}{ Soil } & \multirow{2}{*}{$\begin{array}{c}\text { Dura- } \\
\text { tion } \\
\text { of } \\
\text { test }\end{array}$} & \multirow{2}{*}{$\begin{array}{c}\text { Puddled } \\
\text { wrought } \\
\text { iron } \\
A \\
A\end{array}$} & \multirow{2}{*}{$\begin{array}{c}\text { Puddled } \\
\text { wrought } \\
\text { iron } \\
B\end{array}$} & \multirow{2}{*}{$\begin{array}{c}\text { Cu-Mo } \\
\text { open- } \\
\text { hearth } \\
\text { iron } \\
H\end{array}$} & \multirow{2}{*}{$\begin{array}{c}\text { Low- } \\
\text { carbon } \\
\text { steel } \\
N \\
N\end{array}$} & \multirow{2}{*}{$\begin{array}{c}\begin{array}{c}5 \% \mathrm{Cr} \\
\text { steel }\end{array} \\
P \\
P\end{array}$} & \multirow{2}{*}{$\begin{array}{c}\begin{array}{c}\text { Cu-Ni } \\
\text { steel }\end{array} \\
D\end{array}$} & \multirow{2}{*}{$\begin{array}{c}18 \% \mathrm{Cr} \\
\text { steel } \\
\boldsymbol{X}\end{array}$} & \multirow{2}{*}{$\begin{array}{c}18 \% \mathrm{Cr} \\
8 \%, \mathrm{Ni} \\
\text { steel } \\
R\end{array}$} \\
\hline No. & Type & & & & & & & & & \\
\hline & & & & & & & & & & \\
\hline 53 & & & & & & & & 0.39 & & $\ldots$ \\
\hline $\begin{array}{l}50 \\
56\end{array}$ & & 5. & & & $\begin{array}{r}.35 \\
1.62\end{array}$ & & $\begin{array}{r}.23 \\
1.51\end{array}$ & $\begin{array}{r}.26 \\
.94\end{array}$ & & \\
\hline 57 & & & & & & & 2. & 1. 21 & 0.01 & 0.00 \\
\hline 58 & & & & & 1. & & & 0 & 0.15 & .00 \\
\hline${ }^{5 Y}$ & & & & & & & & & & \\
\hline & & & & & 0. & & & & & \\
\hline & $\mathrm{Su}$ & 5.47 & 0.74 & .73 & .75 & .86 &. & .42 & .0006 & .00 \\
\hline & $\mathrm{Ti}$ & 5.55 & .55 & .44 & .55 & & 6 & 1 & .12 & .02 \\
\hline $\begin{array}{l}64 \\
65\end{array}$ & & & & & & & & & ๑. 05 & 2 \\
\hline & & & & & & & & & & \\
\hline 67 & & & & 4.73 & 4.7 & & 5. & 4. 47 & 1.0 & 00 \\
\hline
\end{tabular}

- Average rates for 2 specimens, except for soil 57 , from which 8 specimens were removed.

- Each ounce per square foot corresponds to an average loss of 0.0015 inch.

- Loss of weight of individual specimens differred from average by more than 50 percent.

It is impossible to make a strictly accurate comparison with respect to corrosion of the wrought and cast specimens because of the differences in the corrosion products. The boundary between corroded and uncorroded wrought iron or steel is well defined, and the corrosion products are easily removed. In cast iron the corrosion products are intermingled with uncorroded iron and graphite, and it was necessary to use a sharp-pointed tool with considerable force to remove the corrosion products.

The low losses of weight of the specimens high in chromium, $R$ and $X$, in poorly aerated soils are surprising in view of the accepted theory which attributes the resistance of such materials to corrosion to a continual break-down and repair of an oxide film. The supply of oxygen in some of these soils was probably very limited, since they were wet and contained much organic matter. 
TABLE 4.-Rates a of loss of weight of cast-iron pipe buried in 1932

[Ounces per square foot per year]

\begin{tabular}{|c|c|c|c|c|c|c|}
\hline \multicolumn{2}{|r|}{ Soil } & \multirow{2}{*}{$\begin{array}{c}\text { Cast } \\
\text { iron } \\
G\end{array}$} & \multirow{2}{*}{$\begin{array}{c}\text { Special- } \\
\text { process } \\
\text { cast iron } \\
I\end{array}$} & \multirow{2}{*}{$\begin{array}{l}\text { Special- } \\
\text { process } \\
\text { cast iron } \\
J\end{array}$} & \multirow{2}{*}{$\begin{array}{l}\text { Low- } \\
\text { alloy } \\
\text { cast iron } \\
C\end{array}$} & \multirow{2}{*}{$\begin{array}{l}\text { High- } \\
\text { alloy } \\
\text { cast iron } \\
E\end{array}$} \\
\hline No. & Type & & & & & \\
\hline 51 & Acadia clay...... & 3.38 & 4. 55 & 4.20 & 5.37 & 0.76 \\
\hline 53 & Cecil clay loam. & .37 & .31 & .34 & .35 & .14 \\
\hline 55 & Hagerstown loam & .45 & .29 & .28 & .29 & 12 \\
\hline 56 & Lake Charles clay. & 2.72 & 1.75 & 2.30 & 1.92 & 1 \\
\hline 57 & 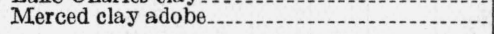 & 1.17 & 1.09 & 1.25 & 1. 51 & \\
\hline 58 & Muck. & 2. 19 & 2.26 & 2.08 & 2.60 & .89 \\
\hline 59 & Peat & .50 & .44 & .48 & .36 & .07 \\
\hline 60 & do do & 1. 36 & 1. 38 & 1. 37 & 1. 27 & \\
\hline 61 & Sharkey clay. & .88 & 1.02 & 1.13 & .86 & 32 \\
\hline 62 & 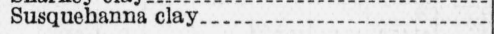 & 1.03 & .77 & .83 & .84 & 20 \\
\hline 63 & Tidal marsh.... & .58 & .50 & .65 & .32 & .10 \\
\hline 64 & Docas clay & 4.17 & 5. 10 & 5.12 & 5.97 & .60 \\
\hline 65 & Alkali soil & 1.17 & 1. 54 & 1. 75 & 2.32 & .57 \\
\hline 66 & Mohave sandy laom & 1.17 & 1.03 & 1. 33 & 2.12 & .57 \\
\hline 67 & Cinders & 9.17 & 9.30 & 9.78 & 6.82 & 7.30 \\
\hline
\end{tabular}

- Averages for 2 specimens except for soil 57 , from which 8 specimens were removed.

Tables 3 and 4 also indicate that the ferrous pipes $D, E, R$, and $X$ containing large percentages of alloying metals lost weight less rapidly than the other ferrous materials. No significant differences were observed in the weight losses in the low-alloy group,

The rates of loss of weight for most materials and most of the soils were less for the 5-year period of exposure than for the 2-year period, [1].

In Lake Charles clay all of the wrought materials except one variety of wrought iron and one containing 2.5 percent of nickel and 1 percent of copper showed higher rates of corrosion for the longer periods of exposure. None of the cast-iron pipes showed this unusual tendency and, until additional specimens, are examined, the significance of the apparent trend in the rate of corrosion of the wrought pipes must remain uncertain.

In the wet peat, soil 59, most of the specimens corroded at about one-fifth of the average rate of corrosion for the 15 soils, whereas the specimens in cinders corroded at approximately three times the average rate (fig. 1). Assuming that protection in soils should be proportional to their corrosiveness, it can be shown that protective measures based on the use of the average corrosiveness of the soils would result in the provision of five times as much protection as is required for the peat soil and only one-third of the protection needed in the cinders. This illustrates the hazard involved in the application of averages to specific soil conditions.

\section{MAXIMUM PENETRATIONS OF THE FERROUS PIPES BURIED IN 1932}

In tables 5 and 6 are given the averages of the depths of the deepest pits on the specimens of each variety of ferrous pipe buried in 1932 . In those cases in which two varieties of pipe were quite similar in chemical composition and in their resistance to soil corrosion, the data for the two similar varieties have been combined. This permits the calculation of the standard errors for the averages of these specimens. 
TABLE 5.-Depths of maximuma pits on wrought ferrous specimens buried in 1932 [In mils]

\begin{tabular}{|c|c|c|c|c|c|c|c|c|c|c|c|c|c|c|c|}
\hline \multirow{3}{*}{ No. } & \multirow{3}{*}{$\begin{array}{l}\text { Soil } \\
\text { Type }\end{array}$} & \multicolumn{5}{|c|}{ Puddled wrought iron } & \multirow{3}{*}{ 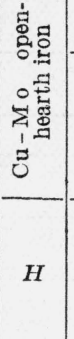 } & \multicolumn{5}{|c|}{ Steel } & \multicolumn{3}{|c|}{ Alloy steel } \\
\hline & & \multirow{2}{*}{$A$} & \multirow[t]{2}{*}{$B$} & \multicolumn{3}{|c|}{$A+B$} & & 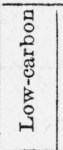 & 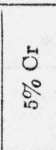 & \multicolumn{3}{|c|}{$N+P$} & 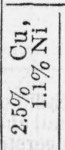 & 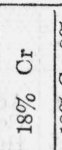 & 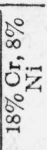 \\
\hline & & & & 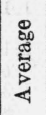 & 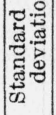 & 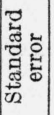 & & $N$ & $P$ & 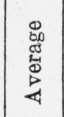 & 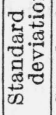 & 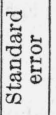 & $D$ & $\boldsymbol{X}$ & $R$ \\
\hline 51 & Acadia clay & 144 & cb $129+$ & & & & e145+ & $154+$ & 105 & & & & 55 & & \\
\hline 53 & Cecil clay 1 & 64 & 71 & 67 & 5 & 3 & 65 & 50 & 56 & 53 & 5 & 3 & 26 & & \\
\hline 55 & Hagerstown loam & 79 & 84 & 81 & 3 & 2 & 75 & 57 & 65 & 61 & 9 & 5 & 34 & &.- \\
\hline 56 & Lake Charles clay & 66 & 65 & 66 & 9 & 5 & 65 & 71 & $154+$ & $112+$ & 44 & 25 & 42 & & \\
\hline 57 & Merced clay adobe & 94 & $100+$ & 97 & 21 & 8 & $113+$ & 100 & 84 & 92 & 22 & 8 & 71 & 610 & \\
\hline 58 & Muck. & 68 & 64 & 66 & 9 & 5 & 60 & 103 & 70 & 86 & 18 & 11 & 71 & b66 & \\
\hline 59 & Peat. & 25 & 18 & 21 & 3 & 2 & 5 & 20 & 32 & 26 & 7 & 4 & 3 & & \\
\hline 60 & & 38 & 37 & 37 & 6 & 4 & เ21 & 24 & 67 & 45 & 22 & 13 & 26 & $\cdots$ & \\
\hline 61 & Sharkey clay & 41 & 37 & 39 & 9 & 5 & b59 & b54 & b37 & 45 & 28 & 16 & 30 & - & \\
\hline 62 & Susquehanna clay. & 54 & 56 & 55 & 7 & 4 & 86 & 66 & 83 & 75 & 13 & 8 & 46 & 4 & $\overline{3}$ \\
\hline 63 & Tidal m & 22 & 37 & 30 & 9 & 5 & b49 & 36 & 87 & 61 & 30 & 17 & & 96 & \\
\hline 64 & Docas clay. & 129 & 110 & 119 & 13 & 8 & 137 & $154+$ & $154+$ & $154+$ & 0 & 0 & 108 & 10 & i \\
\hline 65 & Alkali soil .............. & 91 & 87 & 89 & 13 & 8 & 97 & 74 & 107 & 88 & 14 & 8 & 48 & ... & -- \\
\hline 66 & Mohave sandy loam & 85 & 106 & 95 & 23 & 13 & $145+1$ & $154+$ & 133 & $144+$ & 12 & 7 & 75 & - & \\
\hline 67 & Cinders..... & $145+$ & $145+$ & & & & $118+$ & $119+$ & $112+$ & & & & $145+$ & $145+$ & $\overline{0}$ \\
\hline
\end{tabular}

s A verage of the deepest pit on each of 2 specimens except for soil 57 , from which 8 specimens were removed. All specimens were approximately 5 years old; see table 3 for exact ages.

- Pit depths on individual specimens differed from average by more than 50 percent.

- + indicates that one or more specimens were punctured.

TABLE 6.-Depths of maximum pits ${ }^{a}$ on cast-iron pipe buried in 1932 [In mils]

\begin{tabular}{|c|c|c|c|c|c|c|c|c|c|c|c|c|c|}
\hline \multicolumn{2}{|c|}{ Soil } & \multicolumn{5}{|c|}{ Horizontally cast in sand mold } & \multicolumn{5}{|c|}{ Special process } & \multirow{3}{*}{$\begin{array}{c}\text { Low- } \\
\text { alloy }\end{array}$} & \multirow{3}{*}{$\begin{array}{l}\text { High. } \\
\text { alloy }\end{array}$} \\
\hline \multirow[b]{2}{*}{ No. } & \multirow[b]{2}{*}{ Type } & \multirow[b]{2}{*}{$F$} & \multirow[b]{2}{*}{$G$} & \multicolumn{3}{|c|}{$F+G$} & \multirow[b]{2}{*}{$I$} & \multirow[b]{2}{*}{$J$} & \multicolumn{3}{|c|}{$I+J$} & & \\
\hline & & & & 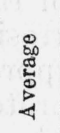 & 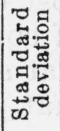 & 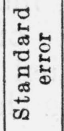 & & & 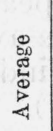 & 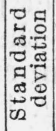 & 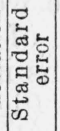 & & \\
\hline $\begin{array}{r}51 \\
53 \\
55 \\
56 \\
57\end{array}$ & $\begin{array}{l}\text { Acadia clay } \\
\text { Cecil clay loam } \\
\text { Hagerstown loam... } \\
\text { Lake Charles clay.-- } \\
\text { Merced clay adobe.- }\end{array}$ & $\begin{array}{c}\text { b250+ } \\
49 \\
66 \\
119 \\
76\end{array}$ & $\begin{array}{c}250+ \\
51 \\
50 \\
109 \\
81\end{array}$ & $\begin{array}{r}(0) \\
50 \\
58 \\
114 \\
78\end{array}$ & $\begin{array}{r}-7 \\
14 \\
14 \\
15\end{array}$ & $\begin{array}{l}4 \\
8 \\
8 \\
9\end{array}$ & $\begin{array}{l}305+ \\
47 \\
56 \\
98 \\
65\end{array}$ & $\begin{array}{l}309+ \\
45 \\
59 \\
93 \\
76\end{array}$ & $\begin{array}{l}\text { (॰) } \\
46 \\
57 \\
95 \\
70\end{array}$ & $\begin{array}{r}11 \\
9 \\
21 \\
11\end{array}$ & \begin{tabular}{|r|r|} 
& 6 \\
5 \\
5 \\
12 \\
6
\end{tabular} & $\begin{array}{c}185+ \\
40 \\
58 \\
101 \\
90\end{array}$ & $\begin{array}{r}50 \\
36 \\
37 \\
32 \\
\text { d } 70\end{array}$ \\
\hline $\begin{array}{l}58 \\
59 \\
60 \\
61 \\
62\end{array}$ & $\begin{array}{l}\text { Muck } \\
\text { Peat } \\
\text { Sharkey clay. } \\
\text { Susquehanna clay. }\end{array}$ & $\begin{array}{r}104 \\
52 \\
60 \\
48 \\
66\end{array}$ & $\begin{array}{c}179+ \\
33 \\
68 \\
55 \\
95\end{array}$ & $\begin{array}{c}142+ \\
42 \\
64 \\
51 \\
81\end{array}$ & $\begin{array}{l}64 \\
10 \\
13 \\
18 \\
20\end{array}$ & \begin{tabular}{r|r}
37 \\
6 \\
7 \\
11 \\
11
\end{tabular} & $\begin{array}{r}107 \\
43 \\
50 \\
83 \\
71\end{array}$ & $\begin{array}{r}109 \\
35 \\
57 \\
60 \\
80\end{array}$ & $\begin{array}{r}108 \\
39 \\
54 \\
72 \\
76\end{array}$ & $\begin{array}{r}20 \\
12 \\
9 \\
13 \\
5\end{array}$ & $\begin{array}{r}11 \\
7 \\
5 \\
7 \\
3\end{array}$ & $\begin{array}{r}124 \\
11 \\
72 \\
44 \\
76\end{array}$ & $\begin{array}{r}34 \\
14 \\
\text { d } 80 \\
39 \\
49\end{array}$ \\
\hline $\begin{array}{r}63 \\
64 \\
65 \\
66 \\
-67\end{array}$ & $\begin{array}{l}\text { Tidal marsh } \\
\text { Docas clay } \\
\text { Alkali soil } \\
\text { Cohave sandy loam }\end{array}$ & $\begin{array}{r}43 \\
116 \\
74 \\
71 \\
250+\end{array}$ & $\begin{array}{c}74 \\
126 \\
94 \\
79 \\
250+\end{array}$ & $\begin{array}{r}58 \\
121 \\
84 \\
75 \\
(0)\end{array}$ & $\begin{array}{r}28 \\
12 \\
23 \\
10 \\
--\end{array}$ & $\begin{array}{r}16 \\
7 \\
14 \\
6 \\
-\end{array}$ & $\begin{array}{c}60 \\
116 \\
95 \\
60 \\
\mathrm{~d} 217+\end{array}$ & $\begin{array}{c}83 \\
104 \\
100 \\
70 \\
\text { d } 210+\end{array}$ & $\begin{array}{r}72 \\
110 \\
97 \\
65 \\
(\mathrm{c})\end{array}$ & $\begin{array}{r}26 \\
15 \\
4 \\
9 \\
--\end{array}$ & $\begin{array}{r}15 \\
9 \\
2 \\
5 \\
-2\end{array}$ & $\begin{array}{c}12 \\
146 \\
91 \\
120 \\
185+\end{array}$ & $\begin{array}{c}16 \\
27 \\
42 \\
36 \\
250+\end{array}$ \\
\hline
\end{tabular}

s Average of deepest pit on each of 2 specimens except for soil 57 , from which 8 specimens were removed. All specimens were approximately 5 years old.

+ indicates that one or more specimens were punctured.

- Soils 51 and 67 are not included in the average, because there are too many holes in the specimens.

d Pit depths on individual specimens differed from average by more than 50 percent. 
The standard errors indicate the reproducibility of the averages and are useful in deciding whether the difference between two averages is characteristic of the materials or due to chance. The decision may be based upon the standard error of the difference between two averages. If the averages are derived from the same number of observations, this may be computed by the equation [6]

$$
\sigma^{2}{ }_{D}=\sigma_{1}^{2}+\sigma_{2}^{2},
$$

in which $\sigma_{D}$ is the standard error of the difference between the two averages, and $\sigma_{1}$ and $\sigma_{2}$ are the standard errors of the two averages. Tables showing the probability of an occurrence of a deviation greater than some multiple of the standard errors of averages will be found in many textbooks on statistics.

Open-hearth iron, $H$ (table 5), differed from the puddled irons, $A$ and $B$, in the process of manufacture and in that material $H$ contained small amounts of copper and molybdenum, whereas the puddled iron contained slag inclusions. The deepest pit shown for material $H$ is less than the average of the deepest pits on materials $A$ and $B$ in 7 of the 15 soils, but in most cases the differences in the pit depths are so small that they may be fortuitous.

Materials $N$ and $P$ differed only in that the latter contained about 5 percent of chromium. The material without chromium, $N$, developed shallower maximum pits than material $P$ in 8 of 13 soils. Holes in both materials prevented a comparison in two soils. The averages of depths of the maximum pits of the puddled-iron specimens, $A$ and $B$, are less than for the averages of the open-hearth steel specimens, $N$ and $P$, in 9 of the 15 soils, but again the differences are not marked in most cases and may be due to chance. Although it seems logical that one material might be superior under some soil conditions and inferior under others, the writer has been unable to associate any soil characteristics with the apparent superiority of any of the materials so far discussed.

With respect to pit depths, nickel-copper steel, $D$, appears to be definitely superior to the other materials so far discussed, although in 13 of the 15 soils the maximum pits on material $D$ were deeper than those on some of the other materials. In three cases the differences were not large.

The specimens of pipe, $R$ and $X$, which contained about 18 percent of chromium, were placed in only six soils. In all soils the pitting of material $R$, which contained 18 percent of chromium and 8 percent of nickel, was definitely the least.

Table 6 shows the averages of the maximum pit depths for two specimens of six varieties of cast iron. Only material $E$, which contained about 15 percent of nickel and 6 percent of copper, was definitely superior to the others with respect to pit depths. This material was also superior, with respect to maximum pit depths, to the wrought materials in table 5 , with the exception of materials $D$, $R$, and $X$, which contained chromium.

Materials $F$ and $G$ differed only in that the adherent molding sand was left on material $F$. This material may have been slightly superior to material $G$, but the difference was not great, perhaps because the surface of material $F$ was not completely covered by sand. On the other hand, the spots where the casting risers were removed 
were painted with portland cement, which slightly reduced the area of the pipe exposed to the soil. The cement may have slightly reduced the acidity of the soil adjacent to the spots.

The relative rates of corrosion of cast iron and steel have been of interest to many pipe users. A little light on this matter may be obtained by comparing the data for averages of materials $F$ and $G$, table 6 , with the averages of materials $N$ and $P$, table 5 . Such a comparison is shown in table 7 , from which it can be seen that there were six soils in which real differences in the materials appeared. This table indicates that the cast iron pitted less than steel in the alkali soils and more deeply than steel in the acid soils.

TABLE 7.-Comparison of specimens of 2-inch steel pipe and 11/2-inch cast-iron pipe with respect to pitting in acid and alkali soils

[Based on a comparison of the averages of the depths of the deepest pits on specimens $N$ and $P$ with the corresponding averages for specimens $F$ and $G$ ]

\begin{tabular}{|c|c|c|c|c|c|c|c|c|c|}
\hline \multicolumn{3}{|c|}{ Acid soils } & \multicolumn{3}{|c|}{$\begin{array}{l}\text { Soils with acidity less than } 14 \\
\text { mg-eq per } 100 \text { grams of soil }\end{array}$} & \multicolumn{3}{|c|}{ Alkali soils } & \multirow{2}{*}{$\begin{array}{c}\text { Soils in } \\
\text { which } \\
\text { both ma- } \\
\text { terials } \\
\text { were } \\
\text { punc- } \\
\text { tured }\end{array}$} \\
\hline $\begin{array}{l}\text { Soils in } \\
\text { which the } \\
\text { deepest } \\
\text { pit was } \\
\text { on cast } \\
\text { iron }\end{array}$ & $\begin{array}{l}\text { Soils in } \\
\text { which the } \\
\text { deepest } \\
\text { pit was } \\
\text { on steel }\end{array}$ & $\begin{array}{c}\text { Soils in } \\
\text { which the } \\
\text { difference } \\
\text { was less } \\
\text { than } 7 \\
\text { mils }\end{array}$ & $\begin{array}{l}\text { Soils in } \\
\text { which the } \\
\text { deepest } \\
\text { pit was } \\
\text { on cast } \\
\text { iron }\end{array}$ & $\begin{array}{c}\text { Soils in } \\
\text { which the } \\
\text { deepest } \\
\text { pit was } \\
\text { on steel }\end{array}$ & \begin{tabular}{|c|} 
Soils in \\
which the \\
difference \\
was less \\
than 7 \\
mils
\end{tabular} & $\begin{array}{l}\text { Soils in } \\
\text { which the } \\
\text { deepest } \\
\text { pit was } \\
\text { on rast } \\
\text { iron }\end{array}$ & \begin{tabular}{|c|} 
Soils in \\
which the \\
deepest \\
pit was \\
on steel
\end{tabular} & $\begin{array}{c}\text { Soils in } \\
\text { which the } \\
\text { difference } \\
\text { was less } \\
\text { than } 7 \\
\text { mils }\end{array}$ & \\
\hline $\begin{array}{r}\text { Identifica- } \\
\text { tion No. } \\
58 \\
59 \\
60\end{array}$ & $\begin{array}{l}\text { None } \\
- \text { do } \\
\text { do }\end{array}$ & $\begin{array}{r}\text { Identifica- } \\
\text { tion No. } \\
62 \\
63 \\
\end{array}$ & \begin{tabular}{c} 
None \\
\hdashline do \\
do
\end{tabular} & $\begin{array}{c}\text { None } \\
\text { do } \\
\text { do }\end{array}$ & $\begin{array}{r}\text { Identifica- } \\
\text { tion No. } \\
53 \\
55 \\
56 \\
61\end{array}$ & $\begin{array}{c}\text { None } \\
\text { do } \\
\text { do }\end{array}$ & $\begin{array}{r}\text { Ideniifica- } \\
\text { tion No. } \\
57 \\
64 \\
66 \\
-\end{array}$ & $\begin{array}{r}\begin{array}{r}\text { Identifica- } \\
\text { tion No. } \\
65\end{array} \\
-\end{array}$ & $\begin{array}{r}\text { Identifica- } \\
\text { tion No. } \\
51 \\
67 \\
\hdashline\end{array}$ \\
\hline
\end{tabular}

It is doubtful, however, whether the relative pit depths on the two materials should be associated with soil acidity or alkali content, since, in the 12-year tests [1], some of the alkali soils were very corrosive with respect to cast iron, whereas the 10 soils in which the pit-cast iron specimens, $L$, were slightly superior to the open-hearth steel specimens, $\bar{K}$, all contained some acid. Table 11 , page 533 , throws some additional light on this subject.

\section{CHANGES IN RATES OF MAXIMUM PENETRATION}

A comparison of the data on pit depths after 5 years, as given in tables 5 and 6 , with similar data for 2-year-old specimens [1] shows that in general the rates of penetration based on exposures of approximately 5 years are much less than those for exposures of 2 years. However, all materials except $D$ and $E$ showed increased rates of penetration for the 5-year period in Lake Charles clay, and one or more materials showed increased rates of corrosion in one or more other soils. No material showed a decreased rate of penetration for the 5-year period of exposure in all soils. The increases were in most cases small and many of them at least may be attributed to chance. Nevertheless, such chance results are not altogether unimportant since the probability of an abnormally deep pit on a specimen must be much less than the probability of a similarly abnormal pit on a pipe having a much larger area. Indeed, the abnormal occurrences 
constitute an important consideration in underground corrosion, since dependability is often a primary consideration in underground construction.

\section{FERROUS PIPES IN MERCED CLAY ADOBE}

Changes in the operations of one of the cooperators necessitated the removal of all the specimens from Merced clay adobe (site 57). This made available the data for eight specimens of each material for the computation of the averages of the losses of weight and of maximum pit depths. These calculations permit a fairly satisfactory comparison of the materials in this soil. For each material the aver-

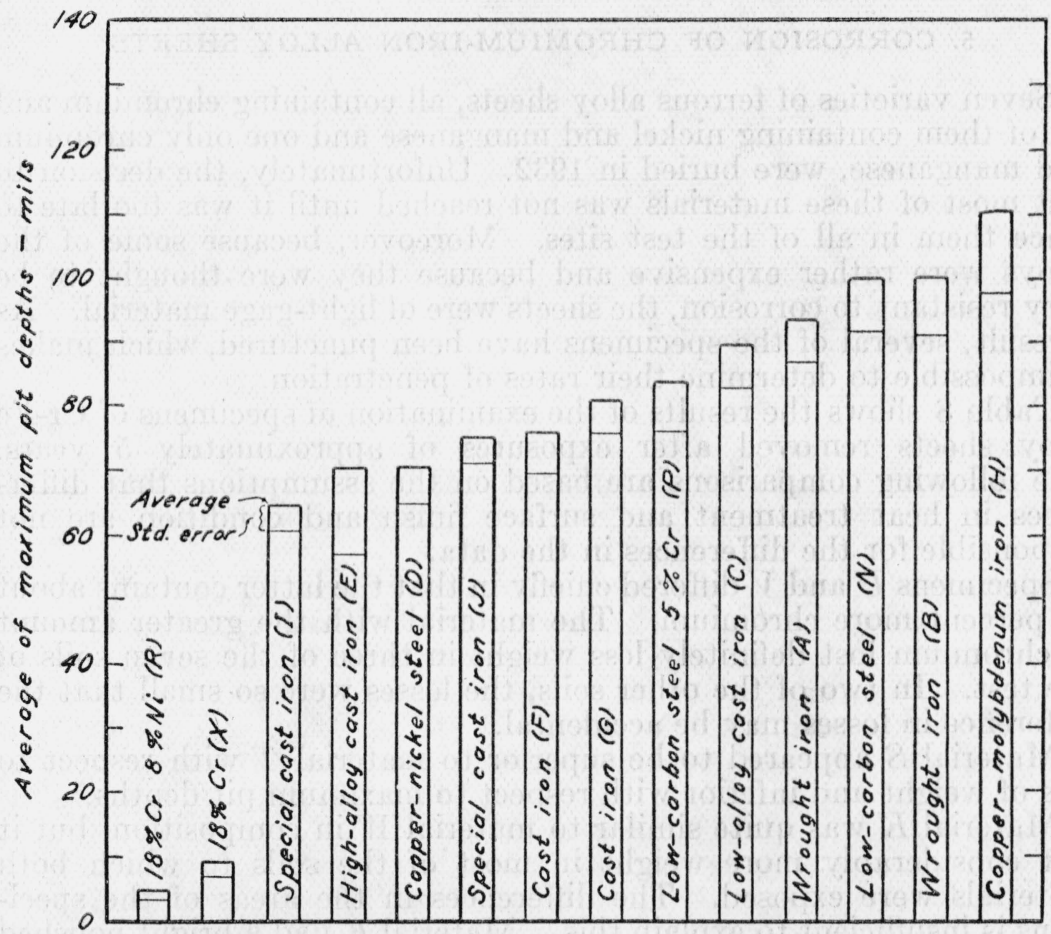

FIGURE 3.-Averages of maximum pit depths on ferrous pipes removed from Merced clay adobe after an exposure of 5 years.

age of the deepest pit on each specimen and the standard error of the average is shown graphically in figure 3.

Obviously, the average of the depths of the deepest pits on the materials containing 18 percent of chromium are much less than those for the other ferrous materials. The number of pits on the chromium alloys was also much smaller. The averages of the maximum pit depths for the other materials do not differ greatly, but the differences are sufficient in some cases to appear to be significant. This is especially true of differences between the maximum pit depths of 
materials $I, J$, and $C$. Figure 3 suggests that the molding sand left on material $F$ may have been somewhat beneficial, since the maximum pit depths on this material are somewhat less than on material $G$, from which all sand was removed. A large number of comparisons could be made and for each comparison the probability of there being a real difference can be determined by the equation previously given. The relative resistances to corrosion shown in figure 3 may not hold for other soil conditions. Thus the figure indicates that the maximum pit depth for material $P$ is considerably less than for material $N$ in Merced clay adobe, whereas table 5 indicates that in 8 of 15 soils the maximum pit depths are less for material $N$ than for material $P$.

\section{CORROSION OF CHROMIUM-IRON ALLOY SHEETS}

Seven varieties of ferrous alloy sheets, all containing chromium and six of them containing nickel and manganese and one only chromium and manganese, were buried in 1932. Unfortunately, the decision to test most of these materials was not reached until it was too late to place them in all of the test sites. Moreover, because some of the alloys were rather expensive and because they were thought to be very resistant to corrosion, the sheets were of light-gage material. As a result, several of the specimens have been punctured, which makes it impossible to determine their rates of penetration.

Table 8 shows the results of the examination of specimens of $\mathrm{Cr}-\mathrm{Fe}$ alloy sheets removed after exposures of approximately 5 years. The following comparisons are based on the assumptions that differences in heat treatment and surface finish and condition are not responsible for the differences in the data.

Specimens $U$ and $V$ differed chiefly in that the latter contains about 50 percent more chromium. The material with the greater amount of chromium lost definitely less weight in three of the seven soils of the test. In two of the other soils, the losses were so small that the difference in losses may be accidental.

Material $S$ appeared to be superior to material $T$ with respect to loss of weight and inferior with respect to maximum pit depths. ${ }^{3}$

Material $K$ was quite similar to material $W$ in composition, but it lost considerably more weight in most of the soils to which both materials were exposed. The differences in the areas of the specimens is insufficient to explain this. Material $K$ had a bright polished surface which is generally supposed to be favorable to corrosion resistance. In soil 60 , one side of one of these specimens was badly corroded, but the other side and both sides of the other specimen of this material were corroded very little. Material $Y$ corroded more than material $W$ in six of the seven soils to which both were exposed, although material $Y$ contained more chromium, nickel, and manganese than material $W$. Both of these materials corroded only very slightly in any of the soils, although some of the soils were very poorly aerated.

A comparison of the 2- and 5-year data on the sheet specimens tends to indicate a decreased rate of loss for the older sheet specimens, but there are a number of exceptions to this conclusion.

\footnotetext{
3 Table 19, page 464, of Research Paper RP883 [1] tends to confirm these observations, but the data are altogether too limited to justify a conclusion.
} 
TABLE 8.-Average loss of weight and maximum penetration of corrosion-resisting steel

\begin{tabular}{|c|c|c|c|c|c|c|c|c|c|c|c|c|c|c|c|c|c|c|c|c|c|c|c|}
\hline \multirow{4}{*}{ No. } & Soil & \multirow{4}{*}{ 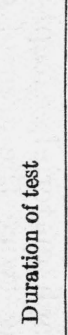 } & \multicolumn{3}{|c|}{$\begin{array}{l}(5) \mathrm{a} \\
11.95 \% \mathrm{Cr}, 0.48 \% \\
\mathrm{Ni}, 0.38 \% \mathrm{Mn}\end{array}$} & \multicolumn{3}{|c|}{$\begin{array}{c}17.08 \% \stackrel{(5)}{\mathrm{Cr}}, 0.09 \% \\
\mathrm{Ni}, 0.36 \% \mathrm{Mn}\end{array}$} & \multicolumn{3}{|c|}{$17.72 \% \stackrel{(2)}{\mathrm{Cr}}, 9.44 \%$} & \multicolumn{3}{|c|}{$\begin{array}{l}17.76 \% \stackrel{(1)}{\mathrm{Cr}}, 3.83 \% \\
\mathrm{Ni}, 6.09 \% \mathrm{Mn}\end{array}$} & \multicolumn{3}{|c|}{$\begin{array}{l}17.2 \% \stackrel{(2)}{\mathrm{Cr}, 8.95 \%} \\
\mathrm{Ni}, 0.44 \% \mathrm{Mn}\end{array}$} & \multicolumn{3}{|c|}{$\begin{array}{l}18.69 \% \stackrel{(5)}{\mathrm{Cr}}, 9.18 \% \\
\mathrm{Ni}, 0.36 \% \mathrm{Mn}\end{array}$} & \multicolumn{3}{|c|}{$\begin{array}{l}22.68 \% \stackrel{(5)}{\mathrm{Cr}, 12.94 \%} \\
\mathrm{Ni}, 1.80 \% \mathrm{Mn}\end{array}$} \\
\hline & \multirow{3}{*}{ Type } & & \multicolumn{2}{|c|}{ Loss } & \multirow{2}{*}{ 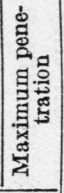 } & \multicolumn{2}{|c|}{ Loss } & \multirow{2}{*}{ 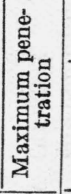 } & \multicolumn{2}{|c|}{ Loss } & \multirow{2}{*}{ 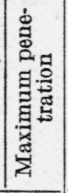 } & \multicolumn{2}{|c|}{ Loss } & \multirow{2}{*}{ 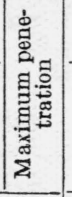 } & \multicolumn{2}{|c|}{ Loss } & \multirow{2}{*}{ 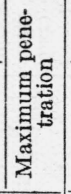 } & \multicolumn{2}{|c|}{ Loss } & \multirow{2}{*}{ 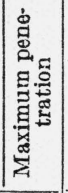 } & \multicolumn{2}{|c|}{ Loss } & \multirow{2}{*}{ 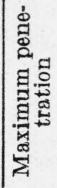 } \\
\hline & & & 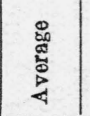 & 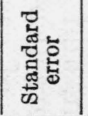 & & 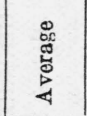 & 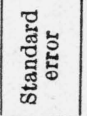 & & 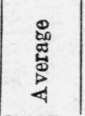 & 莺㟧 & & 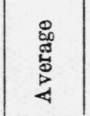 & 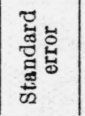 & & 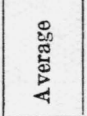 & 总宫 & & 蜜 & 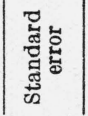 & & 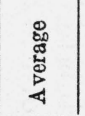 & 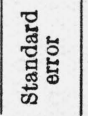 & \\
\hline & & & \multicolumn{3}{|c|}{$U$} & \multicolumn{3}{|c|}{$V$} & \multicolumn{3}{|c|}{$S$} & \multicolumn{3}{|c|}{$T$} & \multicolumn{3}{|c|}{$K$} & \multicolumn{3}{|c|}{$W$} & \multicolumn{3}{|c|}{$Y$} \\
\hline $\begin{array}{l}51 \\
53 \\
55\end{array}$ & $\begin{array}{l}\text { Acadia clay } \\
\text { Cecil clay loam }\end{array}$ & $\begin{array}{l}\text { Years } \\
5.45 \\
5.46 \\
5.20\end{array}$ & $\mid$\begin{tabular}{c} 
Grams \\
\hdashline 0.006
\end{tabular} & \begin{tabular}{|c|} 
Grams \\
0.0008
\end{tabular} & Mils & \begin{tabular}{c} 
Grams \\
\hdashline 00026 \\
\end{tabular} & $\begin{array}{c}\text { Grams } \\
0.0033 \\
\end{array}$ & \begin{tabular}{c} 
Mils \\
\hdashline- \\
\hdashline 0 \\
\end{tabular} & Grams & Grams & Mils & Grams & Grams & Mils & $\begin{array}{c}\text { Grams } \\
0.38 \\
.009\end{array}$ & Grams & $\begin{array}{c}\text { Mils } \\
\mathbf{b} 25+ \\
0\end{array}$ & $\mid$\begin{tabular}{c} 
Grams \\
\hdashline 0
\end{tabular} & Grams & Mils & Grams & Grams & Mils \\
\hline $\begin{array}{l}55 \\
56\end{array}$ & $\begin{array}{l}\text { Hagerstown loam } \\
\text { Lake Charles clay.- }\end{array}$ & $\begin{array}{l}5.20 \\
5.44\end{array}$ & 0.006 & 0.0008 & 1 & 0.0026 & 0.0033 & 0 & & & $\cdots$ & & $\cdots$ & -1 & & & $-25+$ & 0.0052 & 0.0024 & 3 & 0.023 & 0.020 & 1 \\
\hline 57 & Merced clay adobe & 5.23 & 2.2 & 1.5 & $63+$ & .90 & .71 & $34+$ & 0.12 & 0.10 & 9 & 0.50 & 0.57 & 5 & .015 & 0.009 & 1 & .006 & .0024 & 3 & .014 & .008 & 3 \\
\hline $\begin{array}{l}58 \\
59 \\
60 \\
61 \\
6\end{array}$ & $\begin{array}{l}\text { Muck } \\
\text { Peat } \\
\text { Sharkey clay. }\end{array}$ & $\begin{array}{l}5.50 \\
5.14 \\
5.25 \\
5.50 \\
5.47\end{array}$ & $047^{.004}$ & $58^{.0017}$ & $\begin{array}{c}3 \\
027+\end{array}$ & $\begin{array}{l}.008 \\
6.9\end{array}$ & $14^{.002}$ & c15 & & & & & & & $\begin{array}{r}.021 \\
010 \\
.018 \\
.021\end{array}$ & & $\begin{array}{c}0 \\
2 \\
014+ \\
0\end{array}$ & $\begin{array}{l}.007 \\
.005\end{array}$ & $\begin{array}{l}.001 \\
.0017\end{array}$ & $\begin{array}{l}0 \\
4\end{array}$ & $\begin{array}{l}.020 \\
.009\end{array}$ & $\begin{array}{l}.0058 \\
.0014 \\
\end{array}$ & $\begin{array}{l}3 \\
3 \\
-\end{array}$ \\
\hline 62 & tanna clay... & 5.47 & & & & & & & & & & & & & .019 & & 0 & & & & $\cdots$ & 1. & \\
\hline $\begin{array}{l}63 \\
64\end{array}$ & $\begin{array}{l}\text { Tidal marsh } \\
\text { Docas clay }\end{array}$ & $\begin{array}{l}5.55 \\
5.22\end{array}$ & & 1.4 & $63+$ & 2.6 & .88 & $54+$ & 4.3 & & $63+$ & 7.5 & & 5 & $\begin{array}{l}.048 \\
.031\end{array}$ & & $\begin{array}{l}2 \\
3\end{array}$ & .017 & .0028 & 4 & .016 & .0081 & 3 \\
\hline 65 & Alkali soil & 5. 26 & .95 & 0.75 & 43 & 1.4 & .76 & $36+$ & & ( & $-\cdots$ & & & & .019 & & 0 & .0036 & .0012 & 3 & .012 & .0057 & 3 \\
\hline $\begin{array}{l}66 \\
67\end{array}$ & $\begin{array}{l}\text { Mohave sandy loam } \\
\text { Cinders }\end{array}$ & $\begin{array}{l}\text { 5. } 28 \\
5.26\end{array}$ & 2.9 & .63 & $54+$ & 3.1 & 1.7 & $11+$ & .013 & & & & & & $\begin{array}{l}.93 \\
.015\end{array}$ & & {$\left[\begin{array}{c}14+ \\
0\end{array}\right.$} & .006 & .0022 & 2 & .014 & .0061 & 3 \\
\hline
\end{tabular}

a The number in parentheses indicates the number of specimens removed from each test site except for soil 67 , from which 4 times this number of specimens have been removed. tindicates that 1 or more specimens contained holes because of corrosion, rendering

the computation of the exact penetration impossible. The thickness of the specimen
has been used as the maximum pit in this case.

- Loss or maximum pit for 1 or more specimens was greater than the average by more than 50 percent. 


\section{CORROSION OF BOLTS}

Specimens of four kinds of malleable iron and steel bolts were removed from three soils after exposures of approximately 5 years. The bolts were of $3 / 4$-inch stock and were approximately 4 inches long. Table 9 shows the losses of weight and depths of the deepest pits on the heads of the specimens.

TABLE 9.-Corrosion of $3 / 4$-inch bolts a

\begin{tabular}{|c|c|c|c|c|c|c|c|c|c|c|c|}
\hline \multicolumn{2}{|r|}{ Soil } & \multirow{3}{*}{$\begin{array}{l}\text { Num- } \\
\text { ber of } \\
\text { speci- } \\
\text { mens } \\
\text { of each } \\
\text { kind }\end{array}$} & \multirow{3}{*}{$\begin{array}{l}\text { Dura- } \\
\text { tion } \\
\text { of test }\end{array}$} & \multicolumn{6}{|c|}{ Malleable iron } & \multicolumn{2}{|c|}{ Steel } \\
\hline \multirow[t]{2}{*}{ No. } & \multirow[t]{2}{*}{ Type } & & & $\begin{array}{c}\text { Loss } \\
\text { (aver- } \\
\text { age) }\end{array}$ & $\begin{array}{l}\text { Aver- } \\
\text { age of } \\
\text { maxi- } \\
\text { mum } \\
\text { pit on } \\
\text { heads }\end{array}$ & $\begin{array}{l}\text { Loss } \\
\text { (aver- } \\
\text { age) }\end{array}$ & $\begin{array}{l}\text { Aver- } \\
\text { age of } \\
\text { maxi- } \\
\text { mum } \\
\text { pit on } \\
\text { heads }\end{array}$ & $\begin{array}{c}\text { Loss } \\
\text { (aver- } \\
\text { age) }\end{array}$ & $\begin{array}{l}\text { A ver- } \\
\text { age of } \\
\text { maxi- } \\
\text { mum } \\
\text { pit on } \\
\text { heads }\end{array}$ & $\begin{array}{c}\text { Loss } \\
\text { (aver- } \\
\text { age) }\end{array}$ & $\begin{array}{l}\text { Aver- } \\
\text { age of } \\
\text { maxi- } \\
\text { mum } \\
\text { pit on } \\
\text { heads }\end{array}$ \\
\hline & & & & \multicolumn{2}{|c|}{$\begin{array}{c}\text { Decarburized } \\
A\end{array}$} & \multicolumn{2}{|c|}{$\begin{array}{l}\text { Not decar- } \\
\text { burized } \\
B\end{array}$} & \multicolumn{2}{|c|}{ High strength } & \multicolumn{2}{|c|}{$D$} \\
\hline $\begin{array}{l}57 \\
59 \\
61\end{array}$ & $\begin{array}{l}\text { Merced clay adobe.... } \\
\text { Peat } \\
\text { Sharkey clay. }\end{array}$ & $\begin{array}{l}4 \\
2 \\
2\end{array}$ & $\begin{array}{r}\text { Years } \\
5.23 \\
5.14 \\
5.50\end{array}$ & $\begin{array}{c}\text { Grams } \\
11 \\
5.6 \\
8.7\end{array}$ & $\begin{array}{r}\text { Mils } \\
61 \\
3 \\
18\end{array}$ & $\begin{array}{c}\text { Grams } \\
13 \\
4.6 \\
11\end{array}$ & $\begin{array}{r}\text { Mils } \\
79 \\
3 \\
35\end{array}$ & $\begin{array}{c}\text { Grams } \\
12 \\
5.3 \\
9.6\end{array}$ & $\begin{array}{r}\text { Mils } \\
44 \\
3 \\
27\end{array}$ & $\left|\begin{array}{c}\text { Grams } \\
10 \\
6.1 \\
10\end{array}\right|$ & $\begin{array}{r}\text { Mils } \\
35 \\
12 \\
43\end{array}$ \\
\hline
\end{tabular}

- These bolts were 4 inches long.

The measurement of pits was confined to the heads of the bolts, because accurate pit measurements on the bodies of the bolts were impracticable. Figure 4 shows the deepest pit on the body of each specimen. Because of the very limited amount of data and the wide dispersion of the measurements, it is impossible to reach a definite conclusion as to the relative merits of the materials. It does not appear, however, that the corrosion of the materials tested is materially affected by any differences they may possess.

\section{COMPARISON OF MAXIMUM PIT DEPTHS ON SPECIMENS OF DIFFERENT DIAMETERS}

Table 10 affords an opportunity to compare the depths of the maximum pits on materials of different dimensions on three different bases. From each soil there were removed one specimen of 6-inch cast-iron pipe, two specimens of 3 -inch cast iron, and two specimens of 3-inch steel pipe, all 6 inches long. There were also removed from each soil two specimens each of wrought iron, of cast iron, and of open-hearth iron, 12 inches long with external diameters of approximately 1.9 inches, and two 10-inch lengths of 2-inch open-hearth steel. By treating the two specimens of each material, except the 6 -inch cast iron, as a single specimen having twice the area of one, it is possible to compare the pit depths on specimens of different materials and dimensions having approximately the same areas, and to obtain an idea of the accuracy of the method of weighting pit depths which was used in earlier soil-corrosion reports. Columns 2 to 7 of table 10 permit such a comparison. 


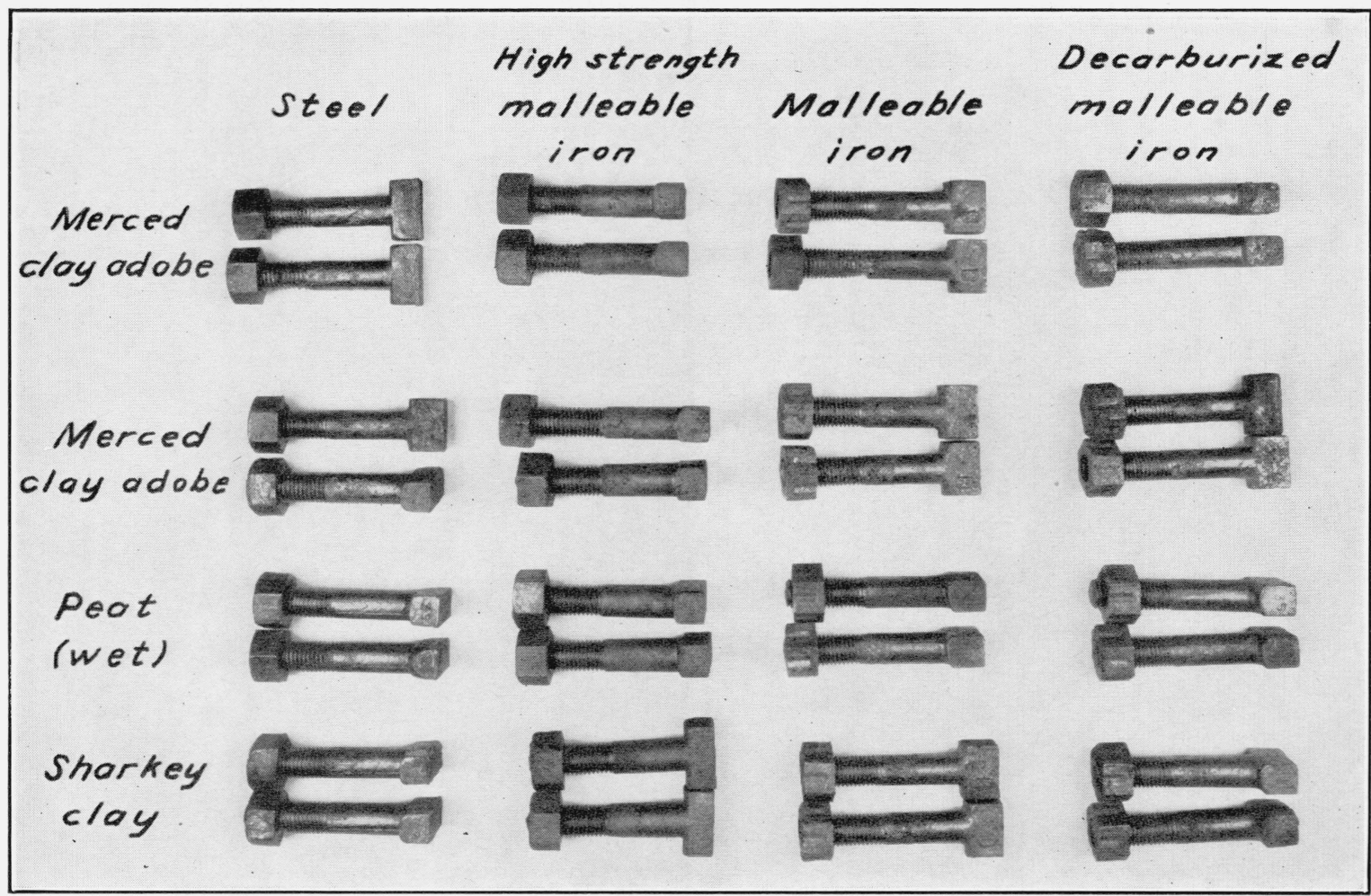

Figure 4.-A ppearance of 3/4- by 4-inch bolts after 5 years of exposure in designated soils. (The"most deeply pitted side of each bolt is shown.) 
TABLE 10.-Maximum pit depths on pipes of different dimensions

[The total area is approximately the same for all diameters of pipe. All specimens were exposed for approximately 5 years]

\begin{tabular}{|c|c|c|c|c|c|c|c|c|c|c|c|c|c|c|c|c|c|c|}
\hline \multirow{4}{*}{ Soil a } & \multicolumn{7}{|c|}{ Single maximum pit (mils) } & \multicolumn{7}{|c|}{ Average of two deepest pits (mils) } & \multicolumn{4}{|c|}{ Weighted $\underset{\text { (mils) }}{\operatorname{maximum}}$ pit depths } \\
\hline & \multicolumn{3}{|c|}{ Cast iron } & \multicolumn{2}{|c|}{ Steel } & \multicolumn{2}{|c|}{ Wrought iron } & \multicolumn{3}{|c|}{ Cast iron } & \multicolumn{2}{|c|}{ Steel } & \multicolumn{2}{|c|}{ Wrought iron } & \multicolumn{3}{|c|}{ Cast iron } & \multirow[b]{2}{*}{$\begin{array}{l}3 \text {-in. } \\
\text { steel }\end{array}$} \\
\hline & 6-in. & 3-in. & $11 / 4$-in. & 3-in. & 2-in. & $\begin{array}{l}11 / 2 \text {-in. } \\
\text { puddled }\end{array}$ & $\begin{array}{l}11 / 2 \text {-in. } \\
\text { open } \\
\text { hearth }\end{array}$ & 6-in. & 3-in. & $11 / 4$-in. & 3 -in. & 2-in. & $\begin{array}{l}\text { 11/2-in. } \\
\text { puddled }\end{array}$ & $\begin{array}{l}11 / 2 \text {-in. } \\
\text { open } \\
\text { hearth }\end{array}$ & 6-in. & 3-in. & $11 / 4$-in. & \\
\hline & 1 & 2 & 3 & 4 & 5 & 6 & 7 & 8 & 9 & 10 & 11 & 12 & 13 & 14 & 15 & 16 & 17 & 18 \\
\hline $58 \ldots . .$. & $\begin{array}{r}199 \\
69 \\
37 \\
92 \\
129\end{array}$ & $\begin{array}{r}-220 \\
56 \\
53 \\
188 \\
132\end{array}$ & $\begin{array}{c}\mathrm{d} 250+ \\
60 \\
50 \\
127 \\
250+\end{array}$ & $\begin{array}{r}80 \\
53 \\
91 \\
185 \\
98\end{array}$ & $\begin{array}{c}\text { d } 54+ \\
53 \\
66 \\
88 \\
108\end{array}$ & $\begin{array}{r}158 \\
67 \\
80 \\
67 \\
79\end{array}$ & $\begin{array}{c}145+ \\
76 \\
96 \\
74 \\
63\end{array}$ & $\begin{array}{r}195 \\
65 \\
34 \\
91 \\
122\end{array}$ & $\begin{array}{r}\circ 182 \\
53 \\
52 \\
178 \\
129\end{array}$ & $\begin{array}{c}250+ \\
51 \\
51 \\
126 \\
250+\end{array}$ & $\begin{array}{r}72 \\
52 \\
86 \\
178 \\
96\end{array}$ & $\begin{array}{c}154+ \\
50 \\
62 \\
82 \\
62\end{array}$ & $\begin{array}{r}144 \\
64 \\
78 \\
67 \\
68\end{array}$ & $\begin{array}{c}145+ \\
65 \\
83 \\
71 \\
105\end{array}$ & $\begin{array}{r}190 \\
55 \\
31 \\
78 \\
113\end{array}$ & $\begin{array}{r}119 \\
42 \\
44 \\
165 \\
109\end{array}$ & $\begin{array}{c}250+ \\
44 \\
50 \\
106 \\
63\end{array}$ & $\begin{array}{r}55 \\
48 \\
76 \\
171 \\
82\end{array}$ \\
\hline 00. & $\begin{array}{r}50 \\
147 \\
65 \\
41 \\
57\end{array}$ & $\begin{array}{r}39 \\
114 \\
80 \\
76 \\
37\end{array}$ & $\begin{array}{r}36 \\
68 \\
77 \\
107 \\
107\end{array}$ & $\begin{array}{r}35 \\
120 \\
60 \\
61 \\
92\end{array}$ & $\begin{array}{r}24 \\
29 \\
\circ 85 \\
66 \\
38\end{array}$ & $\begin{array}{l}25 \\
47 \\
42 \\
56 \\
25\end{array}$ & $\begin{array}{r}6 \\
\circ \quad 34 \\
\circ 94 \\
98 \\
081\end{array}$ & $\begin{array}{r}50 \\
141 \\
60 \\
33 \\
39\end{array}$ & $\begin{array}{r}38 \\
112 \\
76 \\
75 \\
33\end{array}$ & $\begin{array}{r}33 \\
68 \\
76 \\
107 \\
77\end{array}$ & $\begin{array}{r}32 \\
100 \\
60 \\
60 \\
86\end{array}$ & $\begin{array}{r}5 \\
27 \\
\circ 84 \\
66 \\
37\end{array}$ & $\begin{array}{l}24 \\
43 \\
41 \\
56 \\
24\end{array}$ & $\begin{array}{r}23 \\
032 \\
\circ 88 \\
86 \\
\circ 57\end{array}$ & $\begin{array}{r}45 \\
132 \\
56 \\
26 \\
29\end{array}$ & $\begin{array}{r}37 \\
109 \\
58 \\
62 \\
30\end{array}$ & $\begin{array}{c}179+ \\
31 \\
53 \\
54 \\
88\end{array}$ & $\begin{array}{l}29 \\
75 \\
50 \\
57 \\
70\end{array}$ \\
\hline $\begin{array}{l}64 \ldots \\
65- \\
66- \\
67-. .\end{array}$ & $\begin{array}{l}222 \\
140 \\
165 \\
138\end{array}$ & $\begin{array}{r}176 \\
189 \\
163 \\
\\
198\end{array}$ & $\begin{array}{c}139 \\
124 \\
90 \\
250+\end{array}$ & $\begin{array}{r}144 \\
96 \\
217 \\
138\end{array}$ & $\begin{array}{c}154+ \\
79 \\
154+ \\
154+\end{array}$ & $\begin{array}{c}141 \\
102 \\
99 \\
145+\end{array}$ & $\begin{array}{l}143 \\
108 \\
145+ \\
145+\end{array}$ & $\begin{array}{l}220 \\
139 \\
158 \\
111\end{array}$ & $\begin{array}{l}164 \\
164 \\
163 \\
194\end{array}$ & $\begin{array}{c}126 \\
111 \\
83 \\
250+\end{array}$ & $\begin{array}{r}125 \\
87 \\
207 \\
119\end{array}$ & $\begin{array}{c}154+ \\
79 \\
154+ \\
154+\end{array}$ & $\begin{array}{c}129 \\
91 \\
94 \\
145+\end{array}$ & $\begin{array}{l}143 \\
103 \\
145+ \\
145+\end{array}$ & $\begin{array}{r}203 \\
132 \\
150 \\
97\end{array}$ & $\begin{array}{l}149 \\
136 \\
150 \\
(\mathrm{e})\end{array}$ & $\begin{array}{r}57 \\
113 \\
82\end{array}$ & $\begin{array}{r}100 \\
79 \\
157 \\
103\end{array}$ \\
\hline
\end{tabular}

See table 1 for the names of the soils and locations of the test sites. b Average of four deepest pits on one 6-inch specimen, and of the two deepest pits on
each of two specimens of other diameters.

- Individual specimens differed from average by 50 percent or more. 
In 7 of the 14 soils shown in table 10 , the 6 -inch cast-iron specimens developed shallower maximum pits than were observed on equal areas of 3 -inch or $1 \frac{1}{4}$-inch cast specimens, and the average of the maximum pits on the 6-inch specimens is less than the averages for either of the other two sizes of cast-iron pipes. The 3 -inch cast specimens developed shallower maximum pits than were found on the $1 \frac{1}{4}$-inch cast specimens in 6 of the 14 soils, and the average of the maximum pits in the 14 soils is slightly greater for the $1 \frac{1}{4}$-inch cast iron. The 3 -inch steel specimens developed shallower maximum pits than were observed on the 2-inch steel specimens in 5 of the 13 soils for which comparisons are possible.

Comparisons of specimens of different diameters on the basis of the averages of the two deepest pits yield similar results. The data indicate that when the areas of the specimens are the same, the depth of the maximum pit is not affected by the diameter of the specimen.

In earlier reports the pit depths were weighted to take account of the difference in the areas of the specimens. The depths of the four deepest pits were averaged to obtain the recorded maximum pit depths on the 6-inch cast-iron specimens, whereas the depths of the two deepest pits on each of two 3-inch specimens were averaged to obtain the recorded maximum pit depth on the 3 -inch specimens. The 1937 data have been treated in this way to obtain the values in columns 15 , 16 , and 17 of table 10 . In six soils the 6 -inch specimens showed deeper weighted maximum pit depths than the 3-inch cast-iron specimens, whereas in six other soils the weighted maximum pit depths on the 6-inch specimens were shallower. The averages of the weighted maximum pit depths for the 3 sizes of cast pipe in 13 soils differ by only 5 mils. It appears, therefore, that the method used in previous reports for adjusting the data on pit depths to take account of the sizes of the specimens has, on the average, produced results that favored neither size of specimen. This was indicated in the earlier papers with respect to wrought specimens by the averages of the weighted rates of penetration for 11/2- and 3-inch materials of the same kind, but there remained a question as to whether the pit-depth-area relationship held for cast iron.

\section{COMPARISON OF 3-INCH CAST AND WROUGHT SPECIMENS WITH RESPECT TO THEIR DEEPEST PITS}

Table 7 shows that in acid soils the $11_{4}$-inch cast specimens developed deeper maximum pits than those found on the 2-inch steel specimens, although the reverse was true in the alkali soils. In table 11, the data of table 10 have been put in a form similar to that of table 7 . Table 11 shows no relation between the acidity of the soil and the relative merits of the materials. Neither material in this table appears to be definitely superior to the other with respect to the depth of the deepest pits. 
TABLE 11.-Comparison of specimens of 3-inch cast iron and steel pipe with respect to pitting in acid and alkali soils

\begin{tabular}{|c|c|c|c|c|c|c|c|}
\hline \multicolumn{3}{|c|}{ Acid soils } & \multicolumn{3}{|c|}{$\begin{array}{l}\text { Soils with acidity less than } 14 \\
\text { mg-eq per } 100 \text { grams of soil }\end{array}$} & \multicolumn{2}{|c|}{ Alkali soils } \\
\hline $\begin{array}{l}\text { Soils in } \\
\text { which } \\
\text { the } \\
\text { deepest } \\
\text { pit was } \\
\text { on cast } \\
\text { iron }\end{array}$ & $\begin{array}{c}\text { Soils in } \\
\text { which } \\
\text { the } \\
\text { deepest } \\
\text { pit was } \\
\text { on steel }\end{array}$ & $\begin{array}{l}\text { Soils in } \\
\text { which } \\
\text { the } \\
\text { differ- } \\
\text { ence was } \\
\text { less than } \\
5 \text { mils }\end{array}$ & $\begin{array}{l}\text { Soil in } \\
\text { which } \\
\text { the } \\
\text { deepest } \\
\text { pit was } \\
\text { on cast } \\
\text { iron }\end{array}$ & $\begin{array}{l}\text { Soil in } \\
\text { which } \\
\text { the } \\
\text { deepest } \\
\text { pit was } \\
\text { on steel }\end{array}$ & $\begin{array}{l}\text { Soil in } \\
\text { which } \\
\text { the } \\
\text { differ- } \\
\text { ence was } \\
\text { less than } \\
5 \text { mils }\end{array}$ & $\begin{array}{l}\text { Soils in } \\
\text { which } \\
\text { the } \\
\text { deepest } \\
\text { pit was } \\
\text { on cast } \\
\text { iron }\end{array}$ & $\begin{array}{l}\text { Soils in } \\
\text { which } \\
\text { the } \\
\text { deepest } \\
\text { pit was } \\
\text { on steel }\end{array}$ \\
\hline $\begin{array}{c}\text { Identi- } \\
\text { fication } \\
\text { No. } \\
58 \\
62 \\
67\end{array}$ & $\begin{array}{c}\text { Identi- } \\
\text { fication } \\
\text { No. } \\
60 \\
63 \\
--\end{array}$ & $\begin{array}{c}\text { Identi- } \\
\text { fication } \\
N o . \\
56 \\
59 \\
--\end{array}$ & $\begin{array}{c}\text { Identi- } \\
\text { fication } \\
\text { No. } \\
51 \\
-- \\
--\end{array}$ & $\begin{array}{c}\text { Identi- } \\
\text { fication } \\
\text { No. } \\
55 \\
61 \\
--\end{array}$ & $\begin{array}{c}\text { Identi- } \\
\text { fication } \\
\text { No. } \\
53 \\
-- \\
--\end{array}$ & $\begin{array}{c}\text { Identi- } \\
\text { fication } \\
\text { No. } \\
64 \\
65 \\
--\end{array}$ & $\begin{array}{c}\text { Identi- } \\
\text { fication } \\
\text { No. } \\
66 \\
-- \\
--\end{array}$ \\
\hline
\end{tabular}

\section{MATERIALS AT SPECIAL TEST SITES}

A number of small sets of specimens have been placed at test sites to afford information to some cooperator or to obtain data on some special corrosion problem. Most of these sets consisted of two specimens of open-hearth iron, wrought iron, Bessemer steel, pit cast iron, and iron cast centrifugally in green-sand molds. All specimens were 6 inches long. The wrought specimens were cut from 3-inch pipe and the cast specimens from 6-inch pipe.

The data from the examination of such specimens removed in 1937 afford another opportunity to study the effect of variations in composition and methods of manufacture on the resistance of commonly used pipe materials to soil corrosion under special conditions. Table 12 shows the losses of weight of the materials in ounces per square foot. It should be noted that the specimens in three of the soils were exposed for approximately 5 years, whereas the others were exposed for about 9 years. Since rates of corrosion vary with the period of exposure, it seemed inadvisable to reduce the data for two periods of exposure to rates of corrosion and to place them in the same table.

It will be noted that some of the soils were much more corrosive than others. No one material lost less weight than any of the others at all of the test sites.

Table 13 shows the maximum pit depths on the different materials. This table differs from some others in that to make the data for the two sizes of specimens comparable, the two specimens of the same wrought material have been treated as one and the single maximum pit on the two recorded in the table.

It will be seen from table 13 that the three wrought materials corroded quite similarly with respect to the depths of the maximum pits. One or more test sites can be found for each wrought material in which that material developed shallower maximum pits than did either of the other wrought materials. It is evident, therefore, that the averages of the maximum pit depths at all of the test sites would have little practical significance since the relative magnitudes of the averages might have been changed if the materials had been exposed to more or fewer soils. 


\section{TABLE 12.-Loss a of weight of pipe at special test sites}

[In ounces per square foot]

\begin{tabular}{|c|c|c|c|c|c|c|c|c|c|c|c|}
\hline & Soil & & & hch w & ought & mater & & & -inch & ast iro & \\
\hline No. & Type & 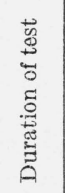 & 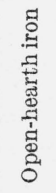 & 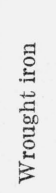 & 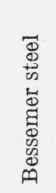 & 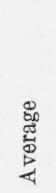 & 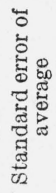 & $\begin{array}{l}\vec{W} \\
\mathbb{\Xi} \\
\vec{A} \\
\vec{F}\end{array}$ & 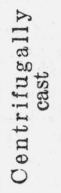 & 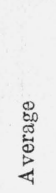 & 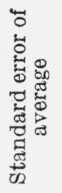 \\
\hline 52 & Alkali knoll & $\begin{array}{c}\text { Years } \\
5.44\end{array}$ & & & & & & 25.2 & 16.2 & 20.7 & \\
\hline 54 & at silt loar & 525 & 1.5 & 1.3 & 1. 2 & 1.3 & 1 & 2.3 & 1.6 & 1.9 & $\begin{array}{r}0.0 \\
.2\end{array}$ \\
\hline 68 & Gila & 5. & 3. & 4. & 3 . & 3 & 3 & 5.3 & b 4 & 5.0 & .3 \\
\hline 101 & Bill & 9 . & 10. & 9 & 9. & & .5 & 10.6 & 8 & 9.3 & 1.0 \\
\hline 102 & Billings silt loam, moderate alkali & 9.27 & 18.3 & 16.1 & 17.6 & 17.3 & .4 & 25.6 & 23.1 & 24.4 & 2.3 \\
\hline 103 & Billings silt loam & 9.27 & 18. & 21.3 & 17. & 19. & .8 & 50.5 & 45.2 & 47 & 5.8 \\
\hline 9 & Fresno sandy loan & 9.24 & 11.7 & 11.8 & 11.3 & 11.6 & & 24.1 & 21.5 & 22.3 & 3.6 \\
\hline 110 & Fresno sandy loam, moderate & & & & & & & & & & \\
\hline & - & 9. 24 & 18.6 & 15.8 & 20.2 & 18. 2 & 1.1 & 17.8 & 19.9 & 18. 3 & 1.8 \\
\hline 111 & Fres & & 17. & & 1 & 18 & .7 & 24.8 & 24 & 24 & 1. 0 \\
\hline & & & & & & & & & & & \\
\hline $\begin{array}{l}117 \\
120\end{array}$ & Merced cls & 9. 27 & 21. 0 & 19.9 & 20.5 & 20.4 & .4 & 19.4 & 15.2 & 17. 3 & 1.5 \\
\hline 120 & Panoche & 9.27 & 5.0 & 4.5 & 7. & 5.5 & .7 & ' 3.8 & 3.5 & 3.6 & 1.0 \\
\hline
\end{tabular}

a A verage losses based on 2 specimens of each material except the pit cast iron, of which there was but 1 specimen.

b One specimen only; cast in a metal mold.

- Losses of individual specimens differed from average by more than 50 percent.

TABLE 13.-Maximum pit depths on specimens at special test sites [In mils]

\begin{tabular}{|c|c|c|c|c|c|c|c|c|c|c|c|c|}
\hline \multirow[b]{3}{*}{ No. } & \multirow{3}{*}{ Soil } & \multirow{3}{*}{ 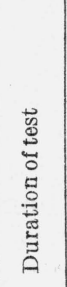 } & \multicolumn{4}{|c|}{$\begin{array}{l}\text { Maximum pit on two } \\
\text { 3-inch specimens }\end{array}$} & \multirow{3}{*}{ 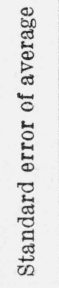 } & \multicolumn{4}{|c|}{$\begin{array}{l}\text { Maximum pits on } 6 \text {-inch } \\
\text { specimens }\end{array}$} & \multirow{3}{*}{ 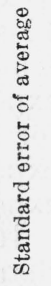 } \\
\hline & & & \multicolumn{2}{|c|}{ Iron } & \multirow{2}{*}{ 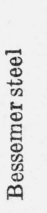 } & \multirow{2}{*}{ 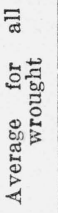 } & & \multirow{2}{*}{ 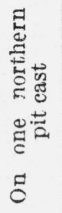 } & \multirow{2}{*}{ 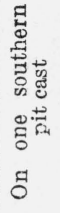 } & \multirow{2}{*}{ 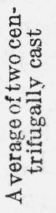 } & \multirow{2}{*}{ 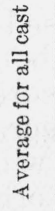 } & \\
\hline & & & 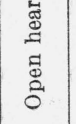 & 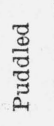 & & & & & & & & \\
\hline & Alkali knoll b & $\begin{array}{l}\text { Years } \\
5.44\end{array}$ & 117 & 134 & 129 & 127 & 5.8 & 195 & 163 & 168 & 175 & 7.3 \\
\hline 54 & Fairmount silt loam & 5. 25 & 15 & 26 & 12 & 18 & 3.5 & 36 & 35 & 57 & 43 & 6.1 \\
\hline 68 & Gila clay & 5.08 & 45 & 46 & 38 & 43 & 2.5 & 93 & 138 & d 82 & 104 & 14.1 \\
\hline 101 & $\begin{array}{l}\text { Billings silt loam, low al- } \\
\text { kali }\end{array}$ & 9.27 & 160 & 96 & 94 & 117 & 20.8 & 128 & 203 & 165 & 165 & 17.7 \\
\hline 102 & $\begin{array}{l}\text { Billings silt loam, moder- } \\
\text { ate alkali. }\end{array}$ & 9.27 & 126 & 105 & 95 & 109 & 6.9 & 410 & 293 & 247 & 317 & 38.7 \\
\hline 103 & Billings silt loam, high al- & 9. 27 & 213 & 139 & 206 & 186 & 23.6 & 418 & 361 & 214 & 331 & 53.9 \\
\hline 109 & $\begin{array}{l}\text { Fresno sandy loam, low } \\
\text { alkali }\end{array}$ & 9.24 & 125 & 112 & 112 & 116 & 7.6 & 269 & 288 & 226 & 249 & 15.6 \\
\hline 110 & $\begin{array}{l}\text { Fresno sandy loam, moder- } \\
\text { gte alkali. }\end{array}$ & 9. 24 & 177 & 148 & 189 & 171 & 14.3 & 280 & 251 & 277 & 269 & 12.7 \\
\hline 111 & Fresno sandy loam & 8.90 & e $216+$ & 197 & 153 & $189+$ & 16.9 & 265 & 167 & 94 & 175 & 38.4 \\
\hline 116 & 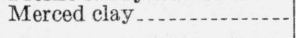 & 9. 27 & 124 & 178 & 97 & 133 & 23.8 & 270 & 250 & 230 & 250 & 12.8 \\
\hline 117 & Merced clay adobe.... & 9.27 & 200 & 133 & 159 & 164 & 19. 5 & 204 & 175 & 167 & 182 & 9.0 \\
\hline 122 & Panoche clay loam.... & 9. 27 & 59 & 52 & 54 & 55 & 2.1 & 90 & 83 & 84 & 86 & 9.4 \\
\hline
\end{tabular}

3 See table 1 for locations of test sites and analyses of soils.

b In Lake Charles clay.

c t indicates specimen punctured.

d One specimen only, cast in a metal mold. The other centrifugally cast specimens were cast in sand molds. 
The situation is much the same with respect to the three cast materials. No one cast material is superior to both of the other materials in all of the soils. Since the test sites do not represent average soil conditions, the table does not indicate the relative maximum pit depths to be expected on different materials except when the conditions of the tests are duplicated. Although these data seem to show that the pit depths are shallower on wrought materials than on cast materials, the data presented in this and earlier papers indicate that probably the commonly used ferrous pipe materials react similarly with respect to loss of weight and pitting when exposed to similar soil conditions, and in a specific case any one of the materials may show a lower rate of lnss of weight or a lower rate of penetration than the others. Such showings may be the result of chance, and it is doubtful whether or not they are of practical importance to the user of underground pipe.

\section{NONFERROUS MATERIALS}

The dimensions and analyses of the nonferrous pipes buried in 1932 are given in table 14. The specimens were cleaned in dilute sulfuric

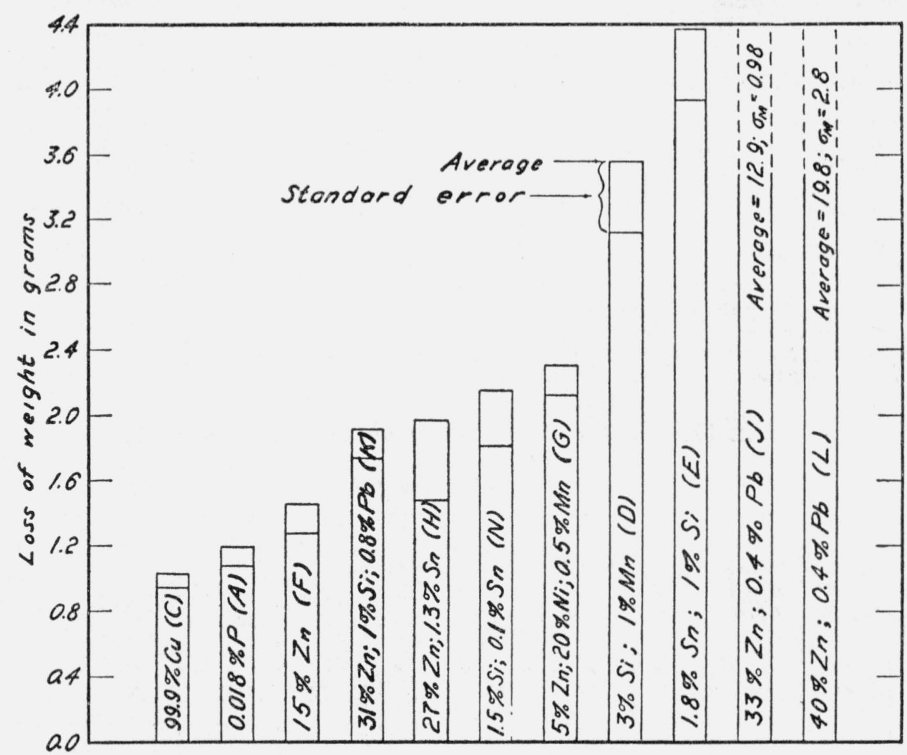

Figure 5.-Losses of weight of nonferrous materials in Merced clay adobe.

acid and weighed and inspected after cleaning to determine their condition. Table 15 shows the rates of loss of weight for the specimens buried for 5 years and is comparable with table 9 of Research Paper RP945 [2], in which the data for the specimens buried for 2 years are given. Losses of weight are not a fair basis for comparing the corrosion-resistant properties of all alloys of copper. Some of them lose strength more rapidly than weight, because of dezincification. The materials which act in this way are indicated in table 16, although the extent of the dezincification was not determined. 
Most of the materials showed rates of loss of weight which are lower for the 5-year period of exposure than for the 2-year period, but in three soils most of the materials showed higher rates of corrosion for the longer periods of exposure. The data are insufficient to show whether or not this apparent tendency is accidental.

Figure 5 permits a comparison of losses of weight of the materials in Merced clay adobe from which a sufficient number of specimens were removed to permit the calculation of the standard errors of the average losses. Whether or not the figure represents the relative resistances of the materials to this soil depends somewhat on the extent of the dezincification of the materials.

TABLE 14.-Chemical composition of 1.7-by 12-inch nonferrous pipe $\mathrm{s}$

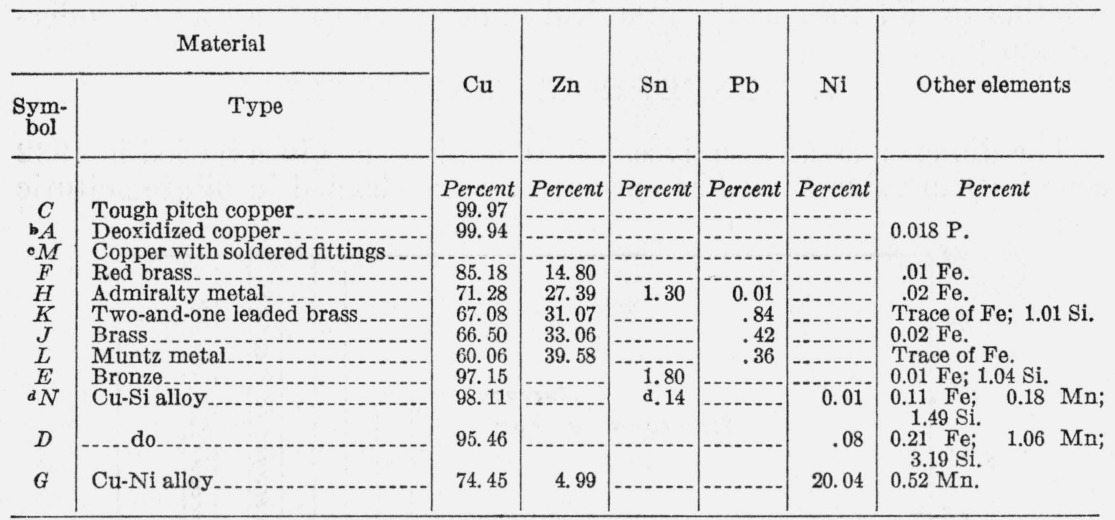

- Analyses furnished by the pipe manufacturers.

Deoxidized copper, hard temper.

- These specimens had streamlined caps and couplings soldered in place.

d Some of these specimens had brazed joints.

TABLE 15.-Rates of loss of weight of nonferrous pipe

[Ounces per square foot per year]

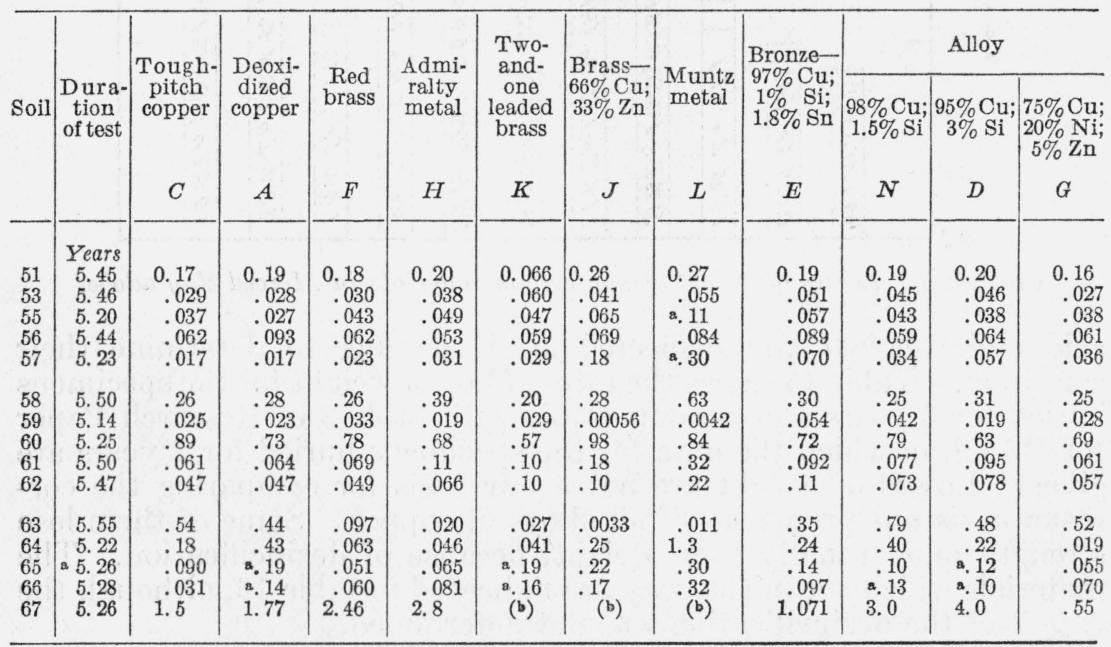

s Individual specimens differed by 50 percent or more from average.

Destroyed by corrosion. 
TABLE 16.-Condition a and rate of maximum penetration of nonferrous pipe

$M=$ shallow metal attack, roughening of surface but no definite pitting. $P=$ definite pitting; rate of pitting less than 1 mil per year. $U=$ apparently unaffected by corrosion. $d=$ selective corrosion in small spots. $Z=$ destroyed by dezincification

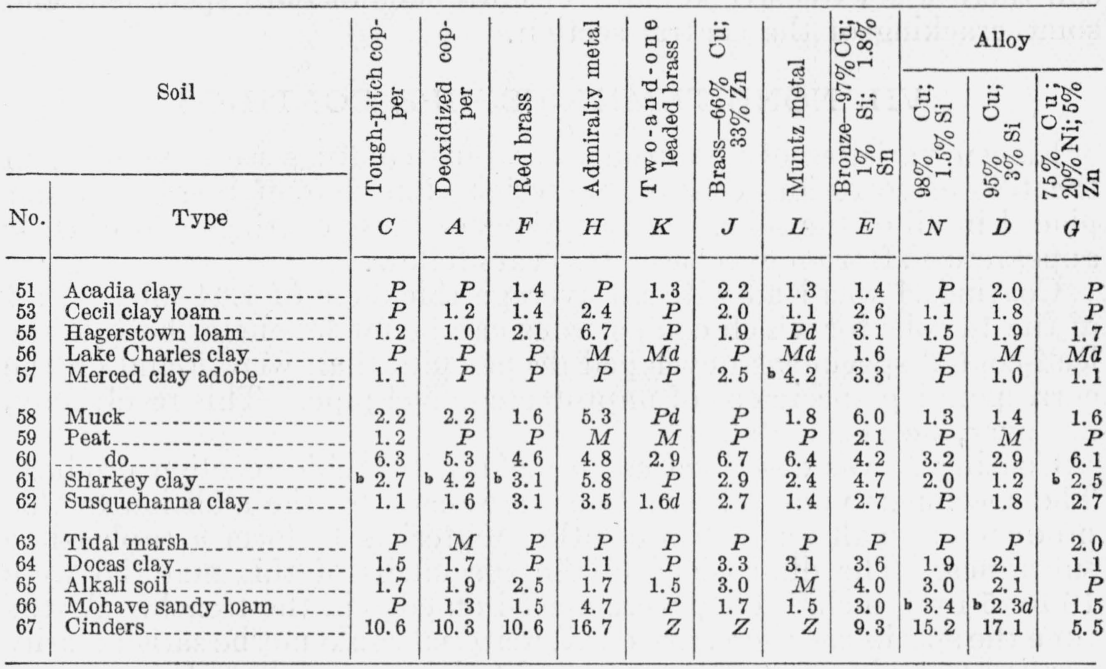

a Averages for 2 specimens for all soils except soil 57 , in which 8 specimens have been averaged; figures in mils per year.

$b$ Individual specimens differed by 50 percent or more from the average

The available data do not justify definite conclusions as to the relative merits of most of the nonferrous specimens. However, at all of the test sites copper and its alloys corroded at much lower rates than the commonly used ferrous materials. The pits on many of the specimens were too shallow to be measured accurately by the methods used. The highest rate of corrosion of the nonferrous as well as the ferrous materials occurred in cinders. Copper and the alloys high in copper developed a hard sulfide scale in the tidal marsh, which was removed by scraping.

The specimens of brass, which contained 30 percent or more of zinc, were destroyed by the cinders, site 67 .

Next to the cinders, one of the peat soils was the most corrosive. The materials high in zinc showed dezincification in a number of soils.

\section{CEMENT-ASBESTOS PIPE}

In 1932 specimens of cement-asbestos flue pipe were included in the test of materials resistant to soil corrosion. Whether or not cement-asbestos water pipe would react to soils in the same way is not known at this time. Specimens of the water pipe were buried at all test sites in 1937 .

In view of the questionable significance of the tests of the flue pipe, and because no test of this material has been found which is satisfactory to all interested parties, it seems sufficient to limit the present report on this material to a few general statements concerning the appearance of the specimens.

In the alkali and neutral soils there appeared to be very little change in the specimens. In the acid soils, except the tidal marsh, there was 
some softening of the surface of the specimens. It is difficult, if not impossible, to determine to what extent the material was softened, but in most soils it did not appear to be serious. In one very acid soil there was extensive swelling of both ends of both specimens and some cracking of the central section.

\section{NONBITUMINOUS PIPE COATINGS}

Eleven varieties of nonbituminous pipe coatings were included in the test of corrosion-resistant materials, but four of these were not placed in all of the soils. Descriptions of these coatings and of their appearance after an exposure of 5 years follow:

Coating $A$ was lead with an average thickness of 1.44 mils. In 4 of the 14 soils for which comparisons can be made, one or both of the lead-coated specimens developed deeper pits than were found on the corresponding specimens of unprotected steel pipe. This result may, however, be accidental.

Coating $B$ was described as an olefin-polysulfide reaction product. The specimens under observation were made by the addition to this product of small quantities of other materials to form a rubber-like substance. The dimensions of the specimens of this material were 10 by 5 by $1 / 4$ inch. They were placed on edge in the trench. At the time the specimens were buried this material could not be satisfactorily applied to a pipe, but there appeared to be a possibility of its use as a pipe coating. It was therefore accepted in the form of sheets. When these were removed in 1937, most of them showed more or less hardening and the surfaces of many specimens cracked when they were bent slightly. This evidence of a change in the material may or may not have a bearing on the use of the material as a pipe coating, since there is usually practically no bending of the coated pipe after it has been placed in the ground.

Coating $C$ was a vitreous enamel described by the manufacturer as acid-resisting, free from pinholes. The thickness of the coating was approximately 14 mils. Although tests with a high-voltage, highfrequency apparatus indicated that there were numerous minute points which would allow current to pass, the specimens showed no definite evidence of rust in any of the soils to which they were exposed. There was little or no indication of a change in the coating. Three specimens were pitted; but it seems probable that these pits formed at points where the specimens had been injured.

Coating $D$ was described as follows: First coat, 23-percent solution of a rubber derivative in xylene; second and third coats, 30-percent solution of the rubber derivative in xylene; fourth coat, 20-percent solution of the rubber derivative in a mixture of turpentine and mineral spirits. Five percent of the solids was carbon black. The thickness of the coating was approximately 0.010 inch. In most soils the outer layer of the coating was brittle and peeled off readily. In a number of soils the coating blistered and the pipe rusted. In seven soils both specimens bore pits of from 27 to 85 mils.

Coating $E$ consisted of two applications of paint which differed in color. Neither the kind of pigment nor the kind of vehicle was specified. The thickness of the coating was approximately 0.005 inch. In most soils this coating blistered and in several of them the coating: came off when the soil was removed from the specimens. The pipe 
rusted badly in several soils and was punctured in three of them. In all soils, however, the coating definitely reduced corrosion.

Coating $F$ was a semiplastic compound, which may be applied cold with a brush, consisting of $4 \frac{1}{2}$ parts of treated cashew-nutshell oil, 3 parts of fiber asbestos, and $3 \frac{1}{2}$ parts of mineral turpentine substitute. The thickness of the coating was approximately 0.006 inch. Twelve of the specimens of coating $F$ were placed in water for 1 week. Pattern tests were then made. All tests indicated pinholes in the coating. On most of the specimens the coating was brittle and many of them contained blisters with rust beneath. In only one soil, however, were the pits on the pipe measurable.

Coating $G$ was a hard-rubber compound containing rubber, sulfur, and an acceleratior cured to a bone-hard condition. The thickness of the coating wrs about 0.09 inch. The bond between the pipe and the coating was not strong.

Coating $H$ was a highly loaded hard-rubber stock which contained 30 percent of magnesium carbonate and approximately 15 percent of "white substitute." The thickness of this coating was about 0.1 inch.

Coatings $G$ and $H$ were exposed to six soils. One specimen of coating $G$ was cracked in one soil and rust appeared near the end of one specimen in one other soil. Coating $H$ completely protected all of the pipe to which it was applied.

Coating $J$ was a modified synthetic resin applied to the pipe in the same manner as a paint or varnish. The pipe was then subjected to a baking operation at $425^{\circ} \mathrm{F}$ for 30 minutes. The thickness of this coating was about 0.002 inch. This coating was removed from only three soils, in one of which it afforded the pipe nearly complete protection.

Coating $K$ was a paint coating containing imported highly chlorinated rubber, which may be dissolved in solvents to which may be added drying oils, pigments, quartz meal, or carborundum. The exact ingredients of the coating, which was applied to the pipe 1 inch in outside diameter, were not stated. The coating was applied in Germany. Its thickness was approximately 0.006 inch. The coating was removed from three soils, in all of which the pipe was pitted to a measurable extent but less deeply than were the bare pipes.

Coating $W$ was an experimental coating prepared as follows: The pipe was primed with a china-wood oil varnish containing zinc chromate and basic lead chromate. This primer was baked at a temperature of about $200^{\circ} \mathrm{F}$ for $1 / 2$ hour. The coating consisted of thoroughly dehydrated china-wood oil to which was added powdered mica and a catalyst. This mixture was molded on the pipe and heated to $200^{\circ} \mathrm{F}$ for 3 hours. The thickness of this coating was about 0.17 inch.

One or more of the coatings cracked in eight of the soils. The adhesion between the coating and the primer was not good. The primer blistered in several of the soils. Although there was slight rusting of most of the specimens, there was no pitting on any of the specimens, and most of the surface of all of the specimens remain uncorroded. The odor of some of the specimens indicated a change in the material.

Table 17 summarizes the condition of the pipe beneath each coating, except coating $B$, which was not applied to a pipe. In general, it may be said that after 5 years, with the exception of one coating at one test site, all of the coated pipe appeared to be in much better 
condition than the uncoated steel pipe in the same soil. However, the brittleness of the thin coatings and the presence of rust beneath them at most of the test sites suggests that they had reached the end of their usefulness in the more corrosive soils.

TABLE 17.-Condition of coated pipes

$C=$ Cracked. $\quad D=$ Destroyed. $E=$ Ends corroded. $\quad H=$ Pipe punctured. $M=$ Metal attack-pipe rough ened by corrosion. $R=$ Rusted. $U=$ No corrosion. $+=$ Pipe punctured

[Figures indicate depths of maximum pits in mils]

\begin{tabular}{|c|c|c|c|c|c|c|c|c|c|c|c|c|c|}
\hline & Soil & & & & & & Pipe & coating & & & & & \\
\hline No. & Type & 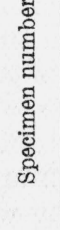 & 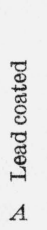 & 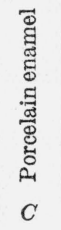 & 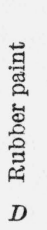 & $\begin{array}{l}\overrightarrow{\vec{G}} \\
\overrightarrow{\text { ت }} \\
E\end{array}$ & 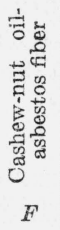 & 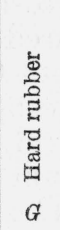 & 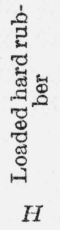 & 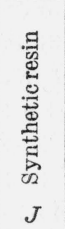 & 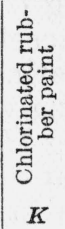 & 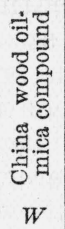 & 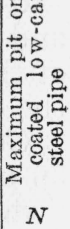 \\
\hline 51 & & & & $U$ & & & $M$ & & & & & $R C$ & $54+$ \\
\hline 51 & Acadia clay - . & 3 & $H$ & 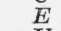 & 8 & 6 & $M$ & & & & & $R C$ & $154+$ \\
\hline 53 & Cecil clay loam & $\begin{array}{l}1 \\
2\end{array}$ & $\begin{array}{l}37 \\
37\end{array}$ & $\underset{U}{U}$ & $\frac{R}{R}$ & $M$ & $\stackrel{R}{R}$ & & & $\begin{array}{l}R \\
R\end{array}$ & $\begin{array}{l}10 \\
16\end{array}$ & $\stackrel{R}{R}$ & 47 \\
\hline 55 & Hagerstown loar & 1 & 17 & $U$ & $R$ & $M$ & $R$ & & & & & $R$ & 48 \\
\hline & Lacosto & 2 & 34 & $U$ & $B$ & $M$ & $R$ & -- & & -. & - & $M$ & 66 \\
\hline 56 & Lake Charles clay ... & 2 & 37 & $E$ & $\begin{array}{l}39 \\
27\end{array}$ & $\begin{array}{l}M \\
32\end{array}$ & $\stackrel{M}{M}$ & & & & & $\begin{array}{l}R C \\
R C\end{array}$ & $\begin{array}{l}53 \\
88\end{array}$ \\
\hline & & $\begin{array}{l}1 \\
2\end{array}$ & $\begin{array}{l}52 \\
55\end{array}$ & $\stackrel{19}{U}$ & $\begin{array}{l}\vec{M} \\
27\end{array}$ & $\begin{array}{l}M \\
M\end{array}$ & $\begin{array}{l}R \\
R\end{array}$ & $\begin{array}{l}U \\
U\end{array}$ & $\begin{array}{l}U \\
U\end{array}$ & $\begin{array}{l}65 \\
43\end{array}$ & $\begin{array}{l}29 \\
36\end{array}$ & $\begin{array}{l}R C \\
R C\end{array}$ & $\begin{array}{r}91 \\
100\end{array}$ \\
\hline & & 3 & 61 & $U$ & $M$ & $M$ & $M$ & $U$ & $U$ & 32 & 25 & $R$ & 140 \\
\hline 57 & Merced clay adobe. & $\begin{array}{l}4 \\
5\end{array}$ & $\begin{array}{l}43 \\
65\end{array}$ & $\stackrel{U}{U}$ & $\begin{array}{l}46 \\
50\end{array}$ & $\frac{M}{M}$ & $\begin{array}{l}R \\
R\end{array}$ & 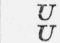 & $\begin{array}{l}U \\
U\end{array}$ & $\begin{array}{l}92 \\
54\end{array}$ & $\begin{array}{l}28 \\
21\end{array}$ & $R C$ & $\begin{array}{l}104 \\
104\end{array}$ \\
\hline & & 6 & 46 & $U$ & 43 & $M$ & $M$ & $U$ & $U$ & 50 & 15 & $M$ & 102 \\
\hline & & $\begin{array}{l}7 \\
8\end{array}$ & $\begin{array}{l}31 \\
45\end{array}$ & $\begin{array}{l}U \\
8\end{array}$ & $\begin{array}{l}30 \\
26\end{array}$ & $\frac{M}{M}$ & $\begin{array}{l}R \\
-R\end{array}$ & $\stackrel{U}{U}$ & $\stackrel{U}{U}$ & $\begin{array}{l}41 \\
48\end{array}$ & $\begin{array}{l}16 \\
25\end{array}$ & $\begin{array}{r}R C \\
U\end{array}$ & $\begin{array}{r}55 \\
103\end{array}$ \\
\hline 58 & $\mathrm{Mu}$ & 1 & 63 & U & $M$ & 70 & $R$ & & & & & $R C$ & $\begin{array}{r}105 \\
97\end{array}$ \\
\hline & & ภ & 61 & $13 E$ & $R$ & $M$ & $R$ & & & & & $R C$ & 108 \\
\hline 59 & Peat. & $\frac{1}{2}$ & $U$ & ${ }_{U}^{U}$ & $U$ & $E$ & $U$ & $U$ & $U$ & ... & 1 & $U$ & 24 \\
\hline 60 & ...... do & 1 & 78 & 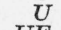 & 57 & 5 & $R$ & $U$ & $U$ & (n) & . & $U$ & $\begin{array}{l}15 \\
18\end{array}$ \\
\hline & & $?$ & 38 & $U H$ & 71 & 6 & $R$ & $U$ & $U$ & -....... & & $M C$ & 29 \\
\hline 61 & Sharkey & $\frac{1}{2}$ & $\begin{array}{l}47 \\
40\end{array}$ & $U$ & $U$ & $M$ & $U$ & $\cdots$ & $\cdots$ & c.....- & & ${ }_{U}^{R C}$ & $\begin{array}{l}23 \\
85\end{array}$ \\
\hline 62 & Susquehanna clay... & 1 & 75 & $U$ & $R$ & $M$ & $R$ & $\cdots$ & ... & $\cdots$ & .- & $R$ & 66 \\
\hline 63 & Tida & 1 & $T T$ & $U$ & $U$ & $M$ & $M$ & - & 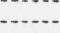 & -...... & ( & $M C$ & 33 \\
\hline & & 2 & $U_{50}^{U E}$ & $U$ & 50 & $M$ & $M$ & $U$ & $U$ & 126 & & $M C$ & $154+$ \\
\hline 64 & Docas cla & 1 & 36 & $U$ & . & H & $M$ & $U$ & $U$ & 59 & & $\tilde{U}$ & $154+$ \\
\hline 65 & Alkali soil.. & 1 & 61 & $-\cdots$ & $M$ & 75 & $\underset{R}{R}$ & $R C$ & $U$ & -. & & $R$ & $\begin{array}{l}79 \\
69\end{array}$ \\
\hline 66 & Mohave sandy loam & 1 & $\begin{array}{l}80 \\
66\end{array}$ & $\begin{array}{c}31 \\
U\end{array}$ & $\begin{array}{l}34 \\
50\end{array}$ & $\begin{array}{l}64 \\
H\end{array}$ & $\frac{M}{M}$ & $\begin{array}{l}U \\
U\end{array}$ & $\begin{array}{l}U \\
U\end{array}$ & & & $\begin{array}{l}R \\
R\end{array}$ & $\begin{array}{l}154+ \\
154\end{array}$ \\
\hline 67 & Cinders... & $\begin{array}{l}1 \\
2\end{array}$ & $\begin{array}{l}D \\
D\end{array}$ & $\underset{E}{U}$ & $\begin{array}{l}55 \\
64\end{array}$ & $\begin{array}{l}H \\
88\end{array}$ & $\begin{array}{l}70 \\
12\end{array}$ & $\frac{E}{U}$ & $\begin{array}{l}U \\
U\end{array}$ & - & 78 & $\underset{U}{U C}$ & $\begin{array}{c}84 \\
154+\end{array}$ \\
\hline & $\begin{array}{l}\text { Thickness of coat- } \\
\text { ing, mils. }\end{array}$ & & 1.4 & 14 & 10 & 5 & 6 & 90 & 100 & 2 & 6 & 170 & \\
\hline
\end{tabular}

\section{SUMMARY}

This report is based on the examination of approximately 1,600 specimens of ferrous and nonferrous materials used for underground pipes and protective coatings. The specimens were removed in 1937, after exposures of from 5 to 9 years.

The tables accompanying the paper afford numerous opportunities for the comparison of soils, pipe materials, and pipe coatings; but since 
the apparent relative merits of materials may be different for different periods of exposure, it is considered best to defer detailed comparisons of materials until data for longer periods are obtained.

The data do not show many marked differences in the corrodibility of ferrous materials made by different processes. The conditions of the test are unfavorable to the detection of small differences in materials.

The addition of small amounts of chromium, copper, nickel, and some other elements to iron or steel appears to have no marked effect on the resistance of the alloys to soil corrosion.

Ferrous alloys containing large amounts of chromium showed definitely lower rates of loss of weight than the other ferrous materials tested. They also had fewer pits per unit area, but the alloys containing chromium alone were pitted deeply in certain soils.

The addition of nickel to chromium-iron alloys appears to improve the alloy with respect to loss of weight and depth of pits. Tests of alloy sheets indicate that sheets containing 23 percent of chromium, 13 percent of nickel, and 1.8 percent of manganese may be less resistant to soil corrosion than an alloy containing somewhat smaller percentages of these elements.

Two ferrous alloys which contained both copper and nickel in considerable amounts resisted soil corrosion better than the other ferrous materials, with the exception of those containing large percentages of chromium. It is difficult to determine from the available data whether the results should be attributed to one or both of the alloying elements.

Copper and its alloys corroded at much slower rates than the commonly used ferrous materials at most of the test sites. The pits on many of the specimens were too shallow to be measured accurately by the methods used. Dezincification affected the specimens containing large percentages of zinc in several soils.

With one exception, all of the coatings examined appeared to have reduced the intensity and amount of corrosion on the pipes to which they were applied as compared with unprotected pipe. However, many of the coatings showed definite signs of deterioration. A vitreous enamel and two thick rubber coatings afforded almost complete, if not entire protection to all of the specimens to which they were applied. These materials showed no visible signs of deterioration.

The work of cleaning the specimens was done mostly by Melvin Romanoff, W. H. Johnson, and J. A. Brooks. The first two men did most of the work necessary for the preparation of the tables. The author is indebted to I. A. Denison, S. P. Ewing, and several cooperating manufacturers for suggestions as to the significance of the data and the form of the report.

\section{REFERENCES}

[1] K. H. Logan, Soil-corrosion studies, 1984. Rates of loss of weight and pitting of ferrous specimens. J. Research NBS 16, 432 (1936) RP883.

[2] Kirk H. Logan, Soil-corrosion studies, 1934. Rates of loss of weight and penetration of nonferrous materials. J. Research NBS 1\%, 782 (1936) RP945.

[3] Kirk H. Logan and Scott P. Ewing, Soil-corrosion studies, 1934. Field tests of nonbituminous coatings for underground use. J. Research NBS 18, 361 (1937) RP982. 
[4] K. H. Logan, S. P. Ewing, and C. D. Yeomans, Bureau of Standards soilcorrosion studies. I. Soils, materials, and results of early observations. BS Tech. Pap. 22, 447 (1927-28) T368.

[5] Kirk H. Logan, Engineering significance of Bureau of Standards soil-corrosion data. J. Research NBS 22, 109 (1939) RP1171.

[6] Arken and Colton, Statistical Methods, p. 120 (Barnes \& Noble, New York, N. Y.).

[7] K. H. Logan and V. A. Grodsky, Soil-corrosion studies, 1930. Rates of corrosion and pitting of bare ferrous specimens. BS J. Research $\boldsymbol{y}, 1$ (1931) RP329.

Washington, August 4, 1939. 